\title{
A REVIEW OF SOLDER GLASSES
}

\author{
R. G. FRIESER \\ IBM System Products Division, East Fishkill, Hopewell Junction, New York 12533
}

(Received June 16, 1975)

\begin{abstract}
A compilation of data on solaer glasses from the literature is presented. Sources are: Chemical Abstracts, Ceramic Abstracts, Abstracts in Physics and Chemistry of Glasses, and pertinent books. Even though not exhaustive, domestic and foreign sources are included.
\end{abstract}

\section{INTRODUCTION}

Data on solder glasses are scattered throughout the technological literature, but primarily throughout the patent and trade literature of glass manufacturers. In most cases, even in the past reviews, the compiled information was concerned with the solution of specific engineering projects ${ }^{1-11}$.

Primary sources for this review were: (a) Chemical Abstracts, (b) Ceramic Abstracts and (c) Abstracts in Physics and Chemistry of Glasses published back to 1948. From these primary sources and from pertinent books, $2,12,1381$ articles and 88 patents were abstracted. The review is an attempt to bring together (from domestic and foreign sources) as much information on solder glasses as possible. Although it is not exhaustive, the author has attempted to cover by far the greater portion of the pertinent literature.

The review is organized in three sections:

1. A general discussion of solder glasses based primarily on information available in the technical literature.

2. A compilation of vendor data on commercially available solder glasses.

3. A survey of the patent literature.

\section{LITERATURE SURVEY OF SOLDER GLASSES}

\subsection{General}

The term solder (or sealing) glass is obviously borrowed from metallurgical techniques. It designates a usage rather than a composition or property of the glass. Thus any glass can (theoretically at least) function as a solder glass, if its properties are such that it forms an adhesive bond between two glasses or between a glass and a metal. The bulk of those glasses referred to in the literature as solder glasses belong to the lead borate or lead borosilicate system. However, other systems can and have been used, and are discussed later in this section.

With few exceptions, present literature (both patent and technical) is concerned with the solution of specific glass-to-metal sealing problems. This is quite understandable from an historical point of view. With the invention and manufacture of light bulbs, glass-to-metal seal technology became an engineering and manufacturing problem of considerable economic importance. It gained increased importance with the mushrooming vacuum tube manufacturing industry.

Glass-to-glass seals were relatively unimportant, and when needed were made by the glass blower using a graded seal when two glasses of different coefficient of expansion had to be joined. ${ }^{14,15}$ Only recently has the microelectronics industry in particular posed packaging problems to the design and manufacturing engineer which involve glass-to-glass sealing. Hence the concern of this review.

\subsection{Physical Characterization of a Solder Glass}

In order for a glass to qualify as a solder glass, it has to meet specific physical criteria. These criteria will depend to a great extent on the properties of the materials the solder glass is to unite. Thus, in general, a good solder glass should have the following characteristics:

\section{Low viscosity}

2. Thermal expansion matching the workpiece

3. Good adhesion

4. High chemical resistivity

5. High dielectric strength

6. Controllable devitrification or no devitrification 


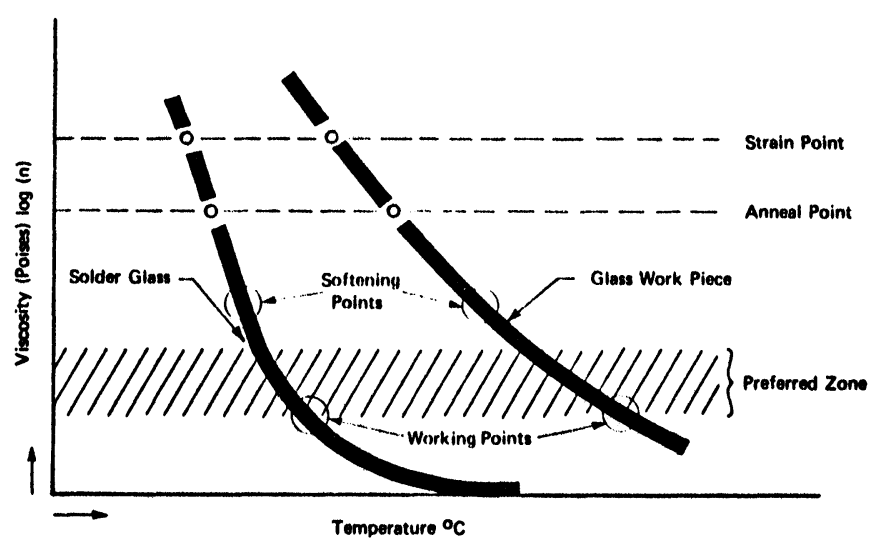

FIGURE 1 Viscosity-temperature relationship of solder glass and work piece.

\subsubsection{Viscosity The long viscous range of glasses} compared with the sharp melting point of metal solders creates special problems in the use of solder glasses. Like metal solders, solder glasses must have a low viscosity or high fluidity at temperatures which leave the work piece (be it metal or glass) unaffected. The "working point" of the solder glass should be less than or at the most close to the annealing point of the workpiece. ${ }^{16}$ In other words, the viscosity of the solder glass at the soldering temperature should be $\sim 10^{5}$ to $10^{6}$ poises while the viscosity of the glass workpiece should not be less than $10^{13}$. In addition to having good flow characteristics, the solder glass should be quick setting; i.e., it should have a steep viscosity vs. temperature curve (Figure 1). Because glasses can be described as "super cooled" liquids and can "flow" even at room temperature, the rate at which the glass flows is not only a function of temperature but of time and load (or pressure). This pressure can be exerted by the weight of the glass itself.

Figure 2 demonstrates that by slightly increasing the soldering temperature, a considerable reduction in the sealing time (time for the solder glass to spread properly to form good hermetic seal) can be achieved. The reverse does not work so favorably. Unfortunately, it is usually more important to reduce the sealing temperature. For glass-to-glass seals, the advantage gained by a slight reduction in sealing temperature can easily be lost by the prolonged times required, and some deformation of the workpiece. (A study of the pressure-time-sealing temperature relationship of glasses could provide useful technical information.)

1.2.2 Thermal expansion Unlike most metals and alloys, the thermal expansivity of glasses is not linear. ${ }^{17}$ For most practical purposes, however, it can be considered linear up to the transformation point (Figure 3), but certainly not beyond. Furthermore, the transformation temperature itself changes with the heating rate. ${ }^{18}$ The linear thermal expansion (TE) is schematically plotted in Figure 3 and temperature points of particular interest are identified along with the viscosities at these temperatures.

Above the transformation point $\left(\mathrm{T}_{\mathrm{g}}\right)$ the glass is

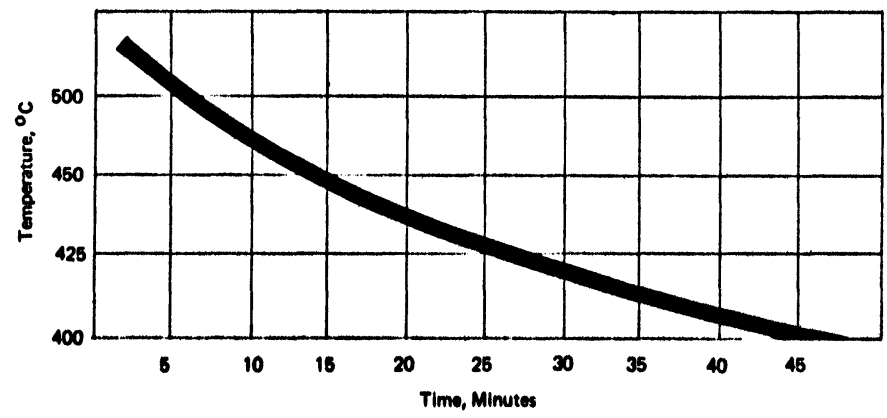

FIGURE 2 Sealing time vs temperature for a typical solder glass. 


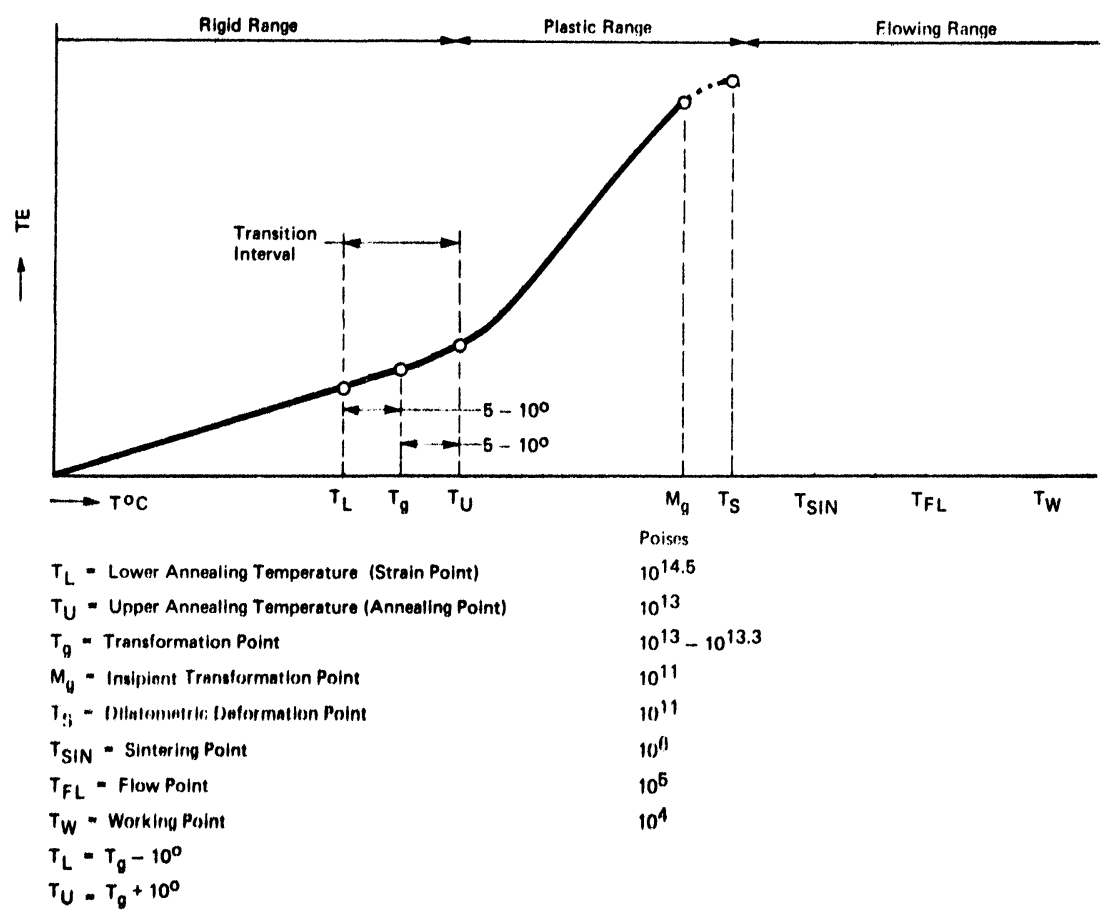

FIGURE 3 Thermal expansion (TE) and relevant viscosities vs temperature of glass.

still plastic and on cooling does accommodate itself to the thermally induced changes in the work piece. ${ }^{1,2}$ As the cooling process continues to $T_{\mathfrak{g}}$, the solder glass becomes rigid and brittle. On further cooling to room temperature, considerable cracking of the solder joint can occur if the contraction rate of the work piece and solder glass differ considerably. ${ }^{1,2,12,13}$ Obviously, then, to obtain strong, stress-free seals, the coefficient of thermal expansion (CTE) of work pieces and solder glass should match in the temperature range from the stress point to room temperature. ${ }^{19}$ Fortunately, because this is rarely possible, a certain amount of mismatch can be tolerated (Figure 4). While the tolerable difference in the CTE's to some extent depends on the geometry of the seal and its use, acceptable limits reported in the literature ${ }^{16}$ for "average conditions" are $\pm 2 \times 10^{-7} /{ }^{\circ} \mathrm{C}$, although mismatches of 1 to $6 \times 10^{-7} /{ }^{\circ} \mathrm{C}$ are still acceptable.

Other studies ${ }^{14,19,20}$ indicate that when the

Differential CTE is: seals are:

$1 \times 10^{-7} /{ }^{\circ} \mathrm{C}$

1 to $5 \times 10^{-7} /{ }^{\circ} \mathrm{C}$

5 to $10 \times 10^{-7} /{ }^{\circ} \mathrm{C}$

$10 \times 10^{-7} /{ }^{\circ} \mathrm{C}$ excellent

satisfactory for medium seals

critical stress

failure

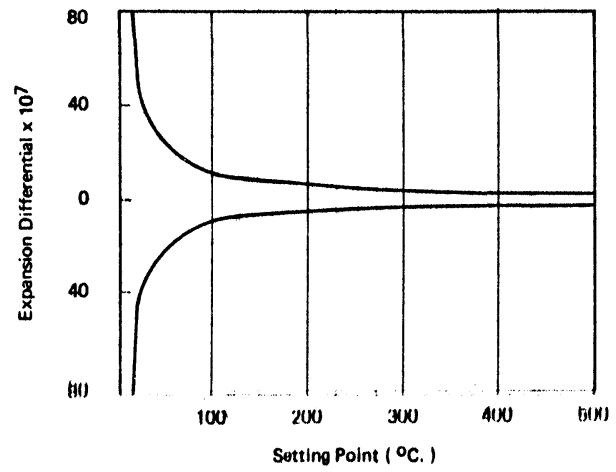

FIGURE 4 Permissible CTE mismatch vs. setting temperature for solder glasses. ${ }^{16}$

Thermal shock, as indicated previously, is a function of the cooling rate and the thickness of the glass layer. Thus, thin layers will withstand thermal shock better for a given CTE mismatch than thicker layers. The thermal endurance of any joint is approximately inversely proportional to the CTE. ${ }^{21}$ A poor match between solder glass and workpiece can at times be overcome by designing a compression seal, since glass only fails in tension. ${ }^{14}$ Because the soldering of workpieces usually involves the joining of different 


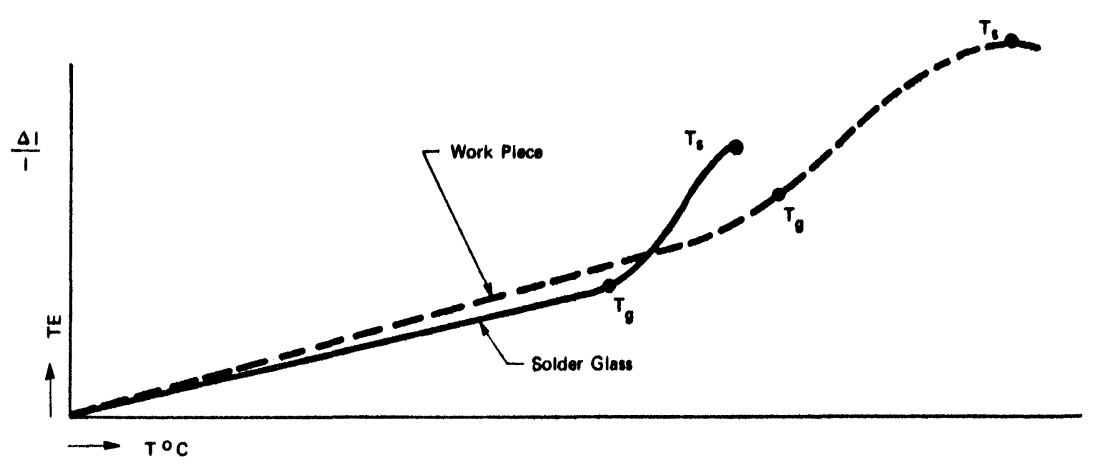

FIGURE 5 Preferred relation of TE curves of solder glass and glass work piece.

materials, the CTE of the solder glass is a very essential parameter. For flat glass-to-metal seals, the conditions prevail that when the CTE metal > CTE glass, the glass is under compressive stresses; when the CTE metal $<$ CTE glass, the glass is under tensile stress. $^{12,20,22-25}$ The total stress picture prevailing in a glass-to-metal seal is far more complicated than in the case of fusion of two different pieces of flat glass; axial, radial and tangential stresses must be taken into account. This is extensively discussed both by Volf ${ }^{2}$ in his chapter on "Sealing Glasses" and by Kohl ${ }^{12}$ in the chapter on "Glass-to-Metal Seals."

In order to obtain strong seals with a minimum of stress when a solder glass with matching CTE (to the workpiece) cannot be found, a solder glass should be selected which meets the following condition: TE solder $<\mathrm{TE}$ workpiece (Figure 5). In the case of joining two glass panels, each having a different TE curve, it is desirable to choose a solder glass with a TE curve lying between that of the other two curves and closer to the curve with the lower values (Figure 6).

In choosing a solder glass with an appropriate $\mathrm{TE}$, the range of greatest interest is the contraction range from the "set point" temperature to room temperature. The set point temperature is a function of the seal geometry, rate of cooling, modulus of elasticity, and the viscosity of the glass. ${ }^{1,2}$ The set point temperature is vaguely defined on the TE curve as $1 / 4$ to $1 / 2$ the distance from the anneal point to the strain

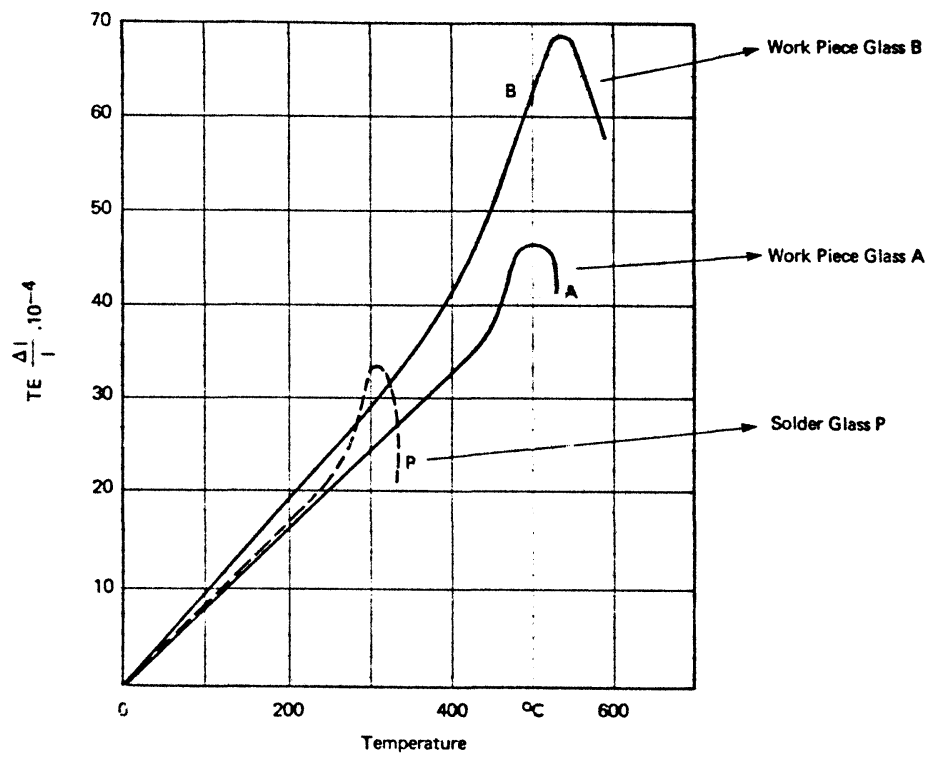

FIGURE 6 Preferred relationship of TE of solder glass curve to work piece TE curve with non-matching TE's. 
point ${ }^{616}$ or somewhat more definite "as $5^{\circ} \mathrm{C}$ above the strain point". ${ }^{19}$ Thus holding the glass at a specific temperature or for a prolonged time in the transformation range and then cooling it quickly causes this temperature to become the set point. ${ }^{22}$

Because of its importance, the CTE is frequently used to classify solder glasses. One such classification establishes three categories: ${ }^{26}$
1) Hard Solder Glasses
$\mathrm{CTE}<25 \times 10^{-7} /{ }^{\circ} \mathrm{C}$
2) Semi Hard Solder Glasses
$\mathrm{CTE}=25-50 \times 10^{-7} /{ }^{\circ} \mathrm{C}$
3) Soft Solder Glasses
CTE $>50 \times 10^{-7} /{ }^{\circ} \mathrm{C}$

A more useful classification separates solder glasses into six groups which correspond to the CTE of the most frequently used metals. ${ }^{23}$ In this review, this latter classification was expanded to eight groups when classifying the solder glass patents in Section 3.

Because the effect of changes in the molecular composition of the glass on the CTE is very important, several authors have derived equations for the calculation of CTE's from glass composition data. These factors were only applicable for the range of compositions for which they were derived. ${ }^{27}$ Sun and Silverman ${ }^{28}$ proposed factors for different oxides in glass making. Appen ${ }^{29}$ developed an equation for high silica glasses, though it fails for low silica glasses.

1.2.3 Adhesion A strong bond between the solder glass and the workpiece implies optimizing adhesion between the two materials. Adhesive bonds obviously can be mechanical as well as chemical, or both. Published data on adhesion between glasses is very often contradictory. Studying the adhesion of borosilicate and soda lime glass to iron, Ikeda and Sameshuma ${ }^{30,31}$ proposed a chemical mechanism (oxyobridges) in borosilicate, but a mechanical mechanism in soda lime glass. In a later publication, Sameshuma ${ }^{32}$ then stated that the Fe-soda lime bond is both chemical and mechanical. A roughened surface is reported to improve any glass to metal adhesion. ${ }^{19}$ Whatever the nature of the bond, the glass at the soldering or work temperature must first wet the surface of the workpiece before any adhesion can take place.

In the case of metals, which ordinarily are coated with a thin film of native oxide, wetting by a glass is greatly enhanced when the oxide has some solubility in the glass. Borate glasses and low melting alkali glasses - most frequently used as solder glasses - are basic in nature thus a chemical attack is possible in some cases. Dissolution of the oxide on the metal or etching the surface of the glass workpiece aids in spreading the solder glass over the surface, or in other words, it lowers the interfacial surface tension of the original work-solder glass surface. ${ }^{20,21,33,34}$ Obviously, the surface of the workpiece must be clean of contaminants. On metals, the thickness of the native oxide layer is critical; at a certain thickness - depending on the oxide - a mechanically weak bond is formed and the seal fails, but if insufficient oxide is present, the solder glass may not form adequate bonds either. ${ }^{12,22,24}$

A word of caution, however, is in order when studying surface characteristics of glass/metal, glass/ceramic or glass/glass interfaces by contact angle measurements. The familiar Young equation, $\gamma_{L} \cos$ $\theta=\gamma_{\mathrm{S}}-\gamma_{\mathrm{SL}}$ assumes that the liquid and solid do not interact nor does any mutual solubility exist between the two. These restraints obviously do not apply to the above mentioned interfaces when molten glass is the liquid forming the contact angle. On the other hand, useful information of a practical nature has been obtained from glass contact angles.

To determine the wetting characteristic of solder glass to a given substrate, measurements of the contact angle of the molten glass on the specific substrate has been reported. ${ }^{20,33,34}$ Espe recommended a static technique. ${ }^{33}$ The contact angle was measured as a function of time at a particular temperature (preferably at the soldering temperature on the substrate in question (Figure 7). A dynamic technique was proposed by Broukal. ${ }^{20}$ Employing a motion picture camera and a high temperature contact angle goniometer, the glass contact angle was determined as

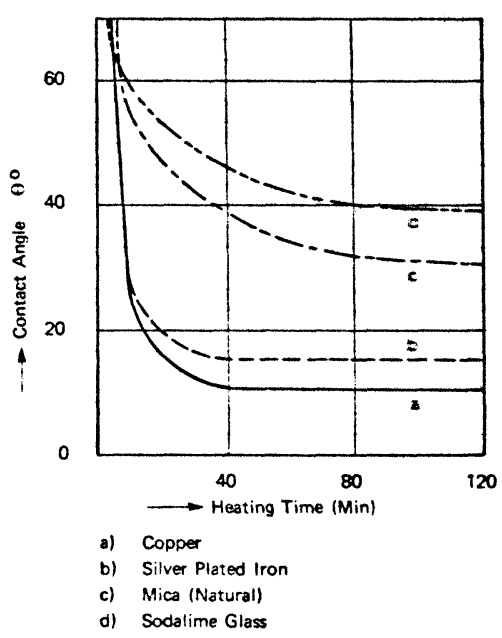

FIGURE 7 Contact angle of $\mathrm{Zn}-\mathrm{Pb}$ borate glass on various substrates. $^{33}$ 
a) Shadow Graph of Contact Angle of Glass on Substrate
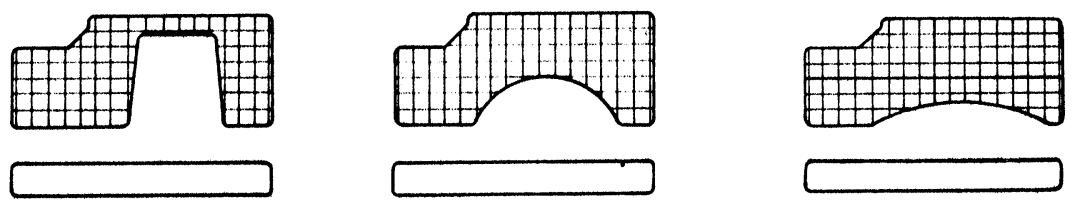

b) Temperature Dependence of Glass Contact Angle

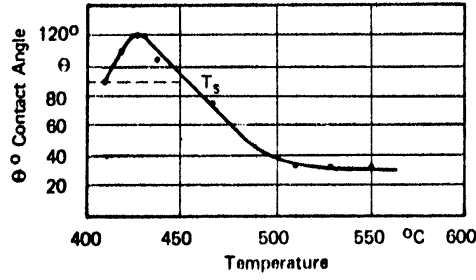

$T_{\mathbf{s}}$ - Soldering Temperature

FIGURE 8 Glass contact angle measurements selected to illustrate the progression of the contact angle with temperature. ${ }^{20}$

a function of temperature (Figure 8a). The temperature on the downward leg of the curve at $90^{\circ}$ was defined as the soldering temperature (Figure $8 \mathrm{~b}$ ); Aoka $^{35}$ called it the sticking temperature; at this temperature the glass begins to wet the substrate. With this technique, Broukal studied the effect of increasing the $\mathrm{B}_{2} \mathrm{O}_{3}$ content on the soldering temperature at constant $\mathrm{PbO}$ content in a $\mathrm{PbO}-\mathrm{ZnO}-\mathrm{B}_{2} \mathrm{O}_{3}$ glass (Figure 9).

Hussmann ${ }^{36}$ suggested that wetting of refractories by metals is a consequence of an electron exchange $(S \rightarrow d)$ of the two materials. Studying changes in the contact angles of molten copper on a series of borides and carbides, he proposed that these changes are proportional to the product of the number of d-shell electrons (of the transition metal forming the boride or carbide). While this "quantitative" approach is not immediately applicable to glass, it could support Weyl and Marboe's ${ }^{37}$ contention that a dynamic interpretation of the adhesion problem based on the changes in the polarizability of the atoms involved is preferable. Thus approaching the adhesion phenomenon of glasses via dispersion force contribution to the surface energy could be more useful in studying various surface conditions and has been used for such purposes. ${ }^{38}$

From a knowledge of the contact angles, the force of adhesion can, at least theoretically, be calculated by either one of the two formulas:

1) $\mathrm{Wa}=\gamma_{\mathrm{gl}}(1+\cos \theta)$

2) $\mathrm{Wa}=2 \sqrt{\gamma_{\mathrm{g} 1}^{\mathrm{d}} \gamma_{\mathrm{s}}^{\mathrm{d}}}$

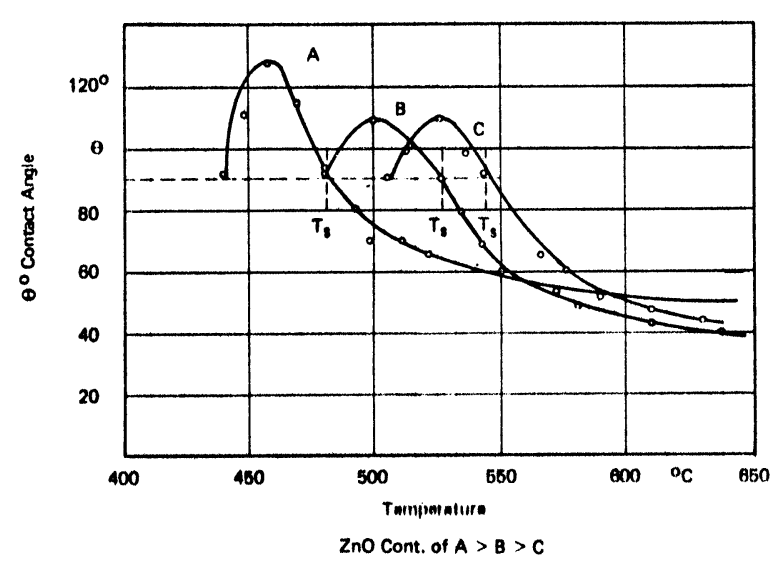

FIGURE 9 Contact angle vs. temperature curves of $\mathrm{Zn}-\mathrm{Pb}$ borate glass. ${ }^{20}$

where $\mathrm{Wa}=$ work of adhesion, $\gamma=$ total surface energy, the subscripts $\mathrm{g} 1$ and $\mathrm{s}$ mean glass and substrate respectively and the superscript $d$ means dispersion force contribution (in this case to the surface energy). Values of $\gamma^{d}$ can be derived from contact angle measurements. ${ }^{40}$ Although these equations have been successfully used for non-polar liquids on low energy surfaces, this author has made some trial calculations of metal-glass systems and obtained "work of adhesion" and "interfacial tensions" which were within $10 \%$ of values published by Kingery. ${ }^{41}$ These results appear encouraging, though this is still a gross over-simplification of the 
glass/metal interface, but possibly a reasonable first approximation.

Other techniques have been proposed for measuring adhesion of glass-metal systems; these are either peel tests ${ }^{42}$ or scratch tests. ${ }^{4-45}$ A technique based on measuring the attenuation of ultrasonic energy has been devised. However, none of these techniques (including the contact angle technique) actually measure the absolute energy of adhesion. This may well be expected since the glass/metal (much less the glass/glass interface) is not a sharp transition of one phase to the other. Rather the glass/metal interface for instance is a transition region with a diminishing metal concentration gradient into the glass surface as shown by several studies. ${ }^{46,47}$ It is therefore questionable what is really measured by the above techniques. Failure between a glass/metal bond invariably occurs in the glass adjacent to the interface. It has never been reported to occur at the "interface" for glass to metal when the glass was cleaned prior to the metal deposition.
Nevertheless, for engineering purposes, a pull test of some sort could be adequate to test the strength of a glass-to-metal joint. Meier ${ }^{24}$ has claimed improved adhesion in glass-to-metal seals when the metal seals were precoated with a thin layer of such metals as $\mathrm{Cr}$, $\mathrm{Cu}, \mathrm{In}, \mathrm{Ag}$, or $\mathrm{Au}$.

1.2.4 Chemical resistivity Strong hermetic seals with solder glass can be obtained by minimizing reboil and the metal, in glass-to-metal seals should not emit gases at the work temperature. ${ }^{14,26}$ Table I gives an indication of the chemical durability of various glasses. Since most solder glasses are essentially of the Pb-borate type, their resistance to chemical attack low compared to other glass types. Glasses of binary compositions of plumbates, borates and phosphates are hygroscopic. ${ }^{7,8}$ While the resistance to attack by water can be improved by the addition of oxides of $\mathrm{Zn}, \mathrm{Zr}, \mathrm{Si}$ and $\mathrm{Al}$ other properties suffer, i.e. softening point, CTE and devitrification. ${ }^{9,10,20,21,25,48-50}$ Various surface treatments such as siliconizing is well known to

TABLE I

Chemical durability of glasses. ${ }^{15}$

\begin{tabular}{|c|c|c|c|c|c|}
\hline \multirow[b]{2}{*}{ Type of Glass } & \multicolumn{2}{|c|}{ Powder Tests } & \multicolumn{3}{|c|}{ Weight Loss Tests, $\mathrm{mg} / \mathrm{sq} \mathrm{cm}$} \\
\hline & $\begin{array}{l}\text { Am. Pharm. } \\
\text { Soc. } \\
\text { (Distil. } \mathrm{H}_{2} \mathrm{O} \text { ), } \\
\% \mathrm{Na}_{2} \mathrm{O} \\
\text { extracted }\end{array}$ & $\begin{array}{c}\text { ASTM-A } \\
\left(\frac{\mathrm{N}}{50} \mathrm{H}_{2} \mathrm{SO}_{4}\right) \\
\% \mathrm{Na}_{2} \mathrm{O} \\
\text { extracted }\end{array}$ & $\begin{array}{c}5 \% \mathrm{HCL} \\
(24 \mathrm{hr}, \\
212 \mathrm{~F})\end{array}$ & $\begin{array}{c}5 \% \mathrm{NaOH} \\
(6 \mathrm{hr}, \\
212 \mathrm{~F})\end{array}$ & $\begin{array}{l}\frac{\mathrm{N}}{50} \mathrm{Na}_{2} \mathrm{CO}_{3} \\
(6 \mathrm{hr}, 212 \mathrm{~F})\end{array}$ \\
\hline Silica Glass & -- & -- & -- & -- & -- \\
\hline 96\% Silica Glass & 0.0003 & 0.002 & 0.0004 & 0.9 & 0.07 \\
\hline Soda-Lime -- Window Sheet & -- & -- & -- & -- & - \\
\hline Soda-Lime -- Plate & 0.03 & -- & - & 0.8 & 0.18 \\
\hline Soda-Lime -- Containers & 0.05 & 0.03 & 0.05 & 0.8 & 1.5 \\
\hline Soda-Lime -- Lamp Bulb & 0.09 & 0.04 & 0.01 & 1.1 & 1.1 \\
\hline Lead Glass -- Electrical & 0.07 & 0.15 & 0.02 & 1.6 & 0.25 \\
\hline Lead Glass -- High Lead & 0.0006 & -- & disintegrated & 3.6 & 0.81 \\
\hline Alumino-Borosilicate-Apparatus & -- & 0.005 & -- & 1.0 & 0.13 \\
\hline Borosilicate -- Low Expansion & 0.0025 & 0.005 & 0.0045 & 1.4 & 0.12 \\
\hline Borosilicate -- Low Elect. Loss & -- & -- & 0.02 & 3.45 & 0.77 \\
\hline Borosilicate -- Tungsten Seal & 0.13 & - & $\begin{array}{c}\text { Completely } \\
\text { leached }\end{array}$ & 3.87 & 1.4 \\
\hline Alumino-Silicate & 0.003 & 0.06 & 0.35 & 0.35 & 0.17 \\
\hline Special -- Alkali-resistant & - & 0.05 & 0.008 & 0.09 & 0.03 \\
\hline
\end{tabular}

Source: Copyrighted Material From Revised New Edition of "Glass Engineering Handbook", by E. B. Shand, Corning Glass Works, Published by McGraw-Hill Book Co., New York. 
improve the glass resistivity towards water. Schroeder ${ }^{51}$ discussed surface effects and surface structures as well as the effect of surface damage on the glass.

Mineral acids and water attack borosilicate glasses differently than aqueous bases. ${ }^{21}$ The latter not only leach out the alkali ions but dissolve the remaining silica gel which the acids would precipitate.

\subsubsection{Electrical properties For most applic-} ations, the electrical conductivity of solder glass is not a problem. However, for metal/glass/metal seals, it can be when an electric potential is impressed on it. Meir $^{24}$ reported electrolytic decomposition of $\mathrm{Pb}$ solder glass in such a seal. $\mathrm{Pb}$ was plated out on one metal electrode while the other corroded when a sufficient potential was placed across the seal.

1.2.6 Devitrification Since all glasses can be considered to be supercooled liquids, they are in a metastable state at room temperature. Therefore they all devitrify when heated for a specific time at a temperature below the liquidus. ${ }^{52-54}$ The rate at which this devitrification takes place varies greatly. For the majority of the commercially useful transparent glasses, this rate at room temperature is so slow that for all practical purposes it is zero. However, for many glasses, especially glass-ceramic systems, ${ }^{53,55}$ it is appreciable and increases rapidly on heating. Because solder glasses must be heated during application, devitrification in such cases becomes a very important consideration. It is convenient, therefore, to separate solder glasses into two general categories: ${ }^{19,52}$ (1) Vitreous solder glasses (2) Devitrifying (crystallizing) solder glasses.

The thermal behaviour of these two types of solder glasses is somewhat analogous to that of thermoplastic and thermosetting polymers respectively. Thus:

1) The vitreous solder glass can be repeatedly reworked while maintaining the same characteristics and properties of the original glass composition.

2) On initial curing, devitrifying solder glasses form crystal nuclei and thus a two-phase system. These glasses are stable at temperatures below the softening point, but above that temperature they not only commence to flow but to crystallize as well. The crystallization rate will depend on the temperature, type of glass composition, mode of preparation, and the prehistory of the glass. ${ }^{7,8}$ The nucleation rate and the rate of crystallization are considered important parameters of devitrifying glasses. The latter determines the crystal type and receives primary attention $^{52}$ since the nucleation rate is largely determined by the thermal prehistory. As the crystallized phase increases, the viscosity drastically decreases and often the CTE. Thus curing times and schedules for

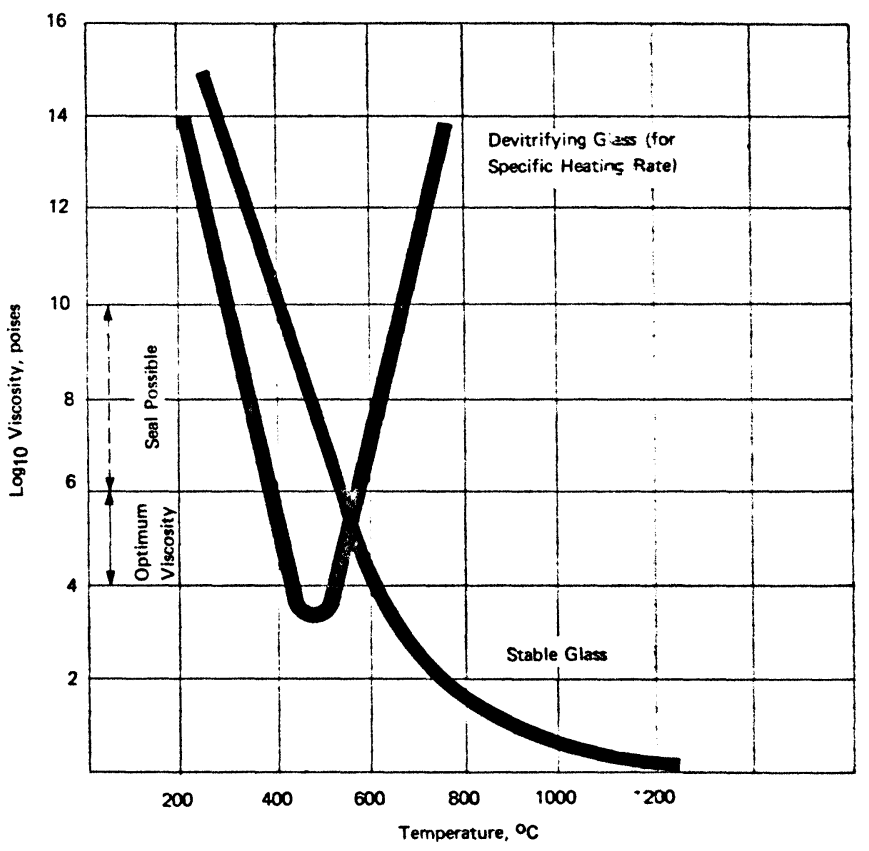

FIGURE 10 Viscosity vs. temperature for a stable and devitrifying solder glass. 
these glasses are rather critical, because these parameters determine the number as well as type of crystal nuclei, ${ }^{55}$ and thus permit control of the nucleation and the glass properties. When devitrification is desired, the objective is to thoroughly crystallize the glass with a minimum of distortion. ${ }^{56}$ That means at as low a temperature and as fast as possible. Figure 10 compares schematically the viscosity changes as a function of temperature of a vitreous and devitrifying glass. The advantages and limitations of devitrifying solder glasses are described in a number of studies. ${ }^{3,52,56}$

There are a number of advantages of the devitrifying solder glasses:

1) Greater joint rigidity is attained at high temperatures.

2) Lower effective thermal expansion is obtained.

3) Thermal expansion maintains compressive stresses more readily in the solder glasses.

4) Lower fillet stresses can be attained.

However, there are also a number of limitations of devitrifying solder glasses:

1) Sufficient flow for a desirable seal may be difficult to achieve.
2) The range is narrow (sometimes too narrow) for sintering prior to crystal growth.

3) Sealing techniques are usually limited to powdered glass technology.

4) Glass quality is usually more difficult to control

5) The final seals are opaque.

Table II demonstrates some of the above points, comparing the ranges of the properties of the two types of commercially-available solder glasses.

Knowledge of the reaction kinetics would be important in choosing a solder glass. Unfortunately, it seldom is available. Some mechanical dispersions of an additive phase can offer the advantage of devitrification by reducing the CTE without increasing the softening point or the transformation point. ${ }^{57}$ The author could not find any relationship between devitrification in $\mathrm{Pb}-\mathrm{Zn}$ borate glasses and the specific surface of the precipitated crystals when adding $\mathrm{SiO}_{2}$, $\mathrm{ZrO}_{2}$ or Eucryptite. If the rigid inclusion in a glass ceramic system has a higher elastic modulus than the matrix, the elastic modulus of the composite will increase as the crystal content increases. Thus as much as a $150 \%$ increase over the strength of the unmodified glass has been reported. ${ }^{57}$

TABLE II

Thermoplastic and thermosetting solder glasses. ${ }^{25}$

THERMOPLASTIC

\begin{tabular}{|c|c|c|c|}
\hline $\begin{array}{l}\text { Corning } \\
\text { Code } \\
\text { Number }\end{array}$ & $\begin{array}{l}\text { Expansion } \\
\text { Range }\end{array}$ & $\begin{array}{l}\text { Sealing } \\
\text { Range }\end{array}$ & $\begin{array}{l}\text { Maximum } \\
\text { Service }\end{array}$ \\
\hline 1826 & $50-55 \times 10^{-7} /{ }^{\circ} \mathrm{C}$ & $700-800^{\circ} \mathrm{C}$ & $450-500^{\circ} \mathrm{C}$ \\
\hline 7570 & $90-95$ & $500-550$ & $350-400$ \\
\hline 8363 & $105-110$ & $400-450$ & $300-325$ \\
\hline 9776 & $130-140$ & $350-400$ & $275-300$ \\
\hline
\end{tabular}

THERMOSETTING

\begin{tabular}{|l|l|l|l|}
\hline $\begin{array}{l}\text { Corning } \\
\text { Code } \\
\text { Number }\end{array}$ & $\begin{array}{l}\text { Expansion } \\
\text { Range }\end{array}$ & $\begin{array}{l}\text { Sealing } \\
\text { Range }\end{array}$ & $\begin{array}{l}\text { Maximum } \\
\text { Service }\end{array}$ \\
\hline $\begin{array}{l}7574 \\
\text { (No. } 45 \text { Cement) } \\
7575 \\
\text { (No. } 89 \text { Cement) } \\
7572 \\
\text { (No. 95 Cement) }\end{array}$ & $40-50 \times 10^{-7} /{ }^{\circ} \mathrm{C}$ & $750-775^{\circ} \mathrm{C}$ & $700-750^{\circ} \mathrm{C}$ \\
\hline
\end{tabular}


Forbes ${ }^{57}$ also reported that these glasses are selfcrystallizing and the maximum content of $2 \% \mathrm{SiO}_{2}$ and $15 \% \mathrm{ZnO}$ is significant and critical for devitrification. The devitrification tendency is unfavourably reduced by addition of $\mathrm{SiO}_{2}$ or $\mathrm{Al}_{2} \mathrm{O}_{3}$, be it deliberate or the result of corrosion product contamination from the crucibles. ${ }^{3}$

The addition of up to $5 \% \mathrm{P}_{2} \mathrm{O}_{5}$ to a $\mathrm{Pb}-\mathrm{Zn}$-borate glass enhances the devitrification process without effecting the CTE, though it does increase the deformation temperature. ${ }^{49}$ Generalizing about the influence of any component on the devitrification behaviour is hazardous to say the least, unless the base glass system and preferably its thermal history are well defined. Nevertheless, some generalities have been reported by Knapp: ${ }^{7,8}$ in the case of borosilicate glasses, devitrification tendencies can be reduced by increasing the alkali or $\mathrm{Al}_{2} \mathrm{O}_{3}$ content or decreasing the $\mathrm{CaO}$ or $\mathrm{MgO}$ content. Knapp also reports that monovalent oxides cause the crystallization of trydimite, whereas divalent oxides favor the formation of crystobalite. If the ratio in a borosilicate glass of $\mathrm{B}_{2} \mathrm{O}_{3} / \mathrm{SiO}_{2}>1$ the rate of crystal growth remains constant. But a ratio of $\mathrm{Al}_{2} \mathrm{O}_{3} / \mathrm{MgO}$ between 0.33 to 0.50 slows down crystallization and narrows the temperature range in which crystallization occurs. Furthermore, devitrification can be catalyzed by the cooling melt in contact with crucible material (i.e., $\mathrm{Pt}$ ).

\subsection{Effect of Chemical Composition on Solder Glasses}

It is desirable to have working temperatures of a solder glass as low as possible. Unfortunately, the term "low melting" glasses in the literature may mean any temperature between $100^{\circ} \mathrm{C}$ to $900^{\circ} \mathrm{C} .^{58}$ Table III gives a general idea of the type of glass, their solder temperature and CTE. On the other hand, Bischoff $^{59}$ designed as low melting glasses wt. compositions of $\mathrm{SiO}_{2} 5$ to $50 \%, \mathrm{~B}_{2} \mathrm{O}_{3} 5$ to $90 \%$ and $\mathrm{PbO}$ 33 to $90 \%$ with a softening point of 370 to $890^{\circ} \mathrm{C}$.

There is a considerable amount of information published in the literature - mostly in the patent literature - on the effect of composition on solder glass properties. These efforts are being far from systematic; i.e., each investigator addressing himself to the solution of a specific problem evaluating usually one or the other parameter only. Most of the glasses are multicomponent systems thus studies of phase diagrams are prohibitively complex. A systematic study is further complicated by the fact that even a small amount (1\%) of constituents can effect such properties as phase separation and microstructure. ${ }^{11,50}$ Therefore, extrapolation from one system to another, even to a similar one, is at best a risky practice. This undoubtably accounts for the large number of patents and confusion in areas which on the surface appear to be rather similar. Given these words of caution, the following will be an attempt to summarize the published work in this area.

In general, for silicate glasses, the addition of alkalies $\mathrm{PbO}, \mathrm{B}_{2} \mathrm{O}_{3}$ up to $15 \%$ and $\mathrm{Al}_{2} \mathrm{O}_{3}$ increases the viscosity while addition of $\mathrm{MgO}, \mathrm{ZnO}, \mathrm{CaO}$ and $\mathrm{Fe}_{2} \mathrm{O}_{3}$ decreases it. The effect of these modifiers is by no means uniform over the entire temperature range; i.e., alkalies have a minimum viscosity particularly in the low temperature range while $\mathrm{CuO}$ increases the viscosity more than any other oxide and

TABLE III

Low melting solder glasses. ${ }^{58}$

\begin{tabular}{|l|c|c|c|}
\hline \multicolumn{1}{|c|}{ Glass Type } & $\begin{array}{c}\text { CTE } \\
\text { X 107 }\end{array}$ & $\begin{array}{l}\text { Deformation } \\
\text { Temp }{ }^{\circ} \mathrm{C}\end{array}$ & $\begin{array}{c}\text { Solder } \\
\text { Temp }{ }^{\circ} \mathrm{C}\end{array}$ \\
\hline $\mathrm{Pb}-$ Tellurite & $170-180$ & $260-300$ & $400-450$ \\
$\mathrm{~Pb}-$ Borate & $75-120$ & $280-430$ & $425-559$ \\
$\mathrm{PbZn}-$ Borate & $70-110$ & $320-450$ & $450-570$ \\
$\mathrm{PbCd}-$ Borate & $80-90$ & & $500-550$ \\
$\mathrm{~Pb}-$ Borosilicate & $40-120$ & $370-700$ & $500-900$ \\
$\mathrm{PbZn}-$ Borosilicate & $75-80$ & $370-100$ & $500-550$ \\
$\mathrm{~Pb}-$ Aluminoborate & $60-85$ & $440-485$ & $550-650$ \\
$\mathrm{Li}-$ Aluminoborate & $60-100$ & $370-515$ & $500-650$ \\
$\mathrm{~Pb}-$ Aluminoborosilicate & $80-95$ & $390-440$ & $520-600$ \\
$\mathrm{NaZn}-$ Borophosphate & $50-150$ & $300-450$ & $450-600$ \\
$\mathrm{CdZn}-$ Borofluorophosphate & $\sim 50$ & $500-550$ & $620-680$ \\
$\mathrm{Zn}-$ Borovanadate & $\sim 50$ & 500 & 620 \\
As-Te-S & $170-420$ & $25-200$ & \\
As-S-J & $300-490$ & $48-160$ & $177-400$ \\
\hline
\end{tabular}


especially at low temperature. At higher temperatures $\mathrm{CuO}$ first decreases and then increases the viscosity again. ${ }^{12}$ Unfortunately, a decrease in the viscosity is usually associated with an increase in the CTE. This result might be expected on theoretical grounds. Since the predominant structure of lead-borosilicate glasses is a rigid network, ${ }^{60}$ any component which breaks this network or acts as a chain terminator (like modifiers) will permit the "clumps" of residual sections of the network to move under a stress gradient and thus lower the viscosity. However, because of the improved mobility, thermal expansion will increase and with it the CTE. The bulk of the solder glasses presently employed belong to the systems of zinc-lead-borates or lead-borosilicates. Modifications of these glasses were made by additions and variations in the network formers and modifiers as well as in the intermediate oxides. ${ }^{54}$

In the high lead $(80 \%)$ borosilicate system, addition of a) $\mathrm{Ag}$ increases the devitrification tendencies; b) $\mathrm{ZnS}$ or CdS imparts phosphorescence to the glass; c) up to $4 \% \mathrm{BaO}$ improves the adhesive strength to metals; and d) up to $1 \%$ alkali oxide raised the value of CTE. ${ }^{25}$ The same system was studied by Dale et al., ${ }^{9,10}$ and Broukal. ${ }^{20}$ Their results are summarized in Table IV. Dale et al. reported that addition of fluorides did not markedly change the softening temperature. The composition which provided maximum chemical durability was reported as: $\mathrm{PbO} 75$ to $55 \%, \mathrm{ZnO} 20$ to $10 \%, \mathrm{~B}_{2} \mathrm{O}_{3} 25$ to $15 \%$, with a deformation temperature of 415 to $500^{\circ} \mathrm{C}$; $\mathrm{CTE}=78$ to $90 \times 10^{-7} /{ }^{\circ} \mathrm{C}$.

An extensive study of lead-silicates, lead-borates, alkali-borates and Cabol Glasses by Abou-El-Azm et. $a l .{ }^{50}$ can be summarized as follows:

1) In lead silicates ( $\mathrm{T}$ soft 394 to $672^{\circ} \mathrm{C}$ ) $\mathrm{T}$ soft can be decreased by:

a) Reducing $\mathrm{SiO}_{2}$ content, replacing $\mathrm{Pb}$ by alk alies $(\mathrm{Li}>\mathrm{Na}>\mathrm{K}$ in terms of effectiveness).

b) Replacing Si by B.

$T$ soft can be increased by replacing:

a) $\mathrm{Pb}$ by alkaline earth

( $\mathrm{Mg}>\mathrm{Ca}>\mathrm{Si}>\mathrm{Ba}>\mathrm{Zn}$ ) oxides.

b) Replacing Si by $\mathrm{Al}$ or $\mathrm{Zr}$.

2) In lead borates ( $T$ soft 430 to $508^{\circ} \mathrm{C}$ ), $\mathrm{T}$ soft can be decrease by:

a) Reducing $\mathrm{B}_{2} \mathrm{O}_{3}$ content.

b) Replacing $\mathrm{Pb}$ by alkalies $(\mathrm{Li} \sim \mathrm{Na} \sim \mathrm{K})$.

c) Replacing $\mathrm{B}_{2} \mathrm{O}_{3}$ by Al.

and increased by:

a) Replacing $\mathrm{Pb}$ by alkaline earth oxides and $(\mathrm{Mg} \sim \mathrm{Zn} \sim \mathrm{Ca} \sim \mathrm{Ba} \sim \mathrm{Sr})$.

b) Replacing $\mathrm{B}$ by $\mathrm{Zr}$ and $\mathrm{Ti}(\mathrm{Ti}>\mathrm{Zr}$ ).

3) In alkali borates ( $\mathrm{T}$ soft 355 to $545^{\circ} \mathrm{C}$ ), $\mathrm{T}$ soft is increased by additions of:

a) Alkalies ( $\mathrm{Li} \mathrm{Na} \mathrm{K}$ ) of even small amounts (0.2\%).

b) $\mathrm{Al}_{2} \mathrm{O}_{3}, \mathrm{MgO}, \mathrm{ZnO}$

c) Decreasing the $\mathrm{B}_{2} \mathrm{O}_{3}$ content.

TABLE IV

Influence of glass composition and properties. ${ }^{20}$

\begin{tabular}{|c|c|c|c|c|c|c|c|c|}
\hline \multirow{2}{*}{$\begin{array}{l}\text { Component } \\
\text { Kept } \\
\text { Constant }\end{array}$} & \multicolumn{3}{|c|}{$\begin{array}{l}\text { Component Being Increased } \\
\text { or Substituted }\end{array}$} & \multicolumn{5}{|c|}{ Properties Influenced } \\
\hline & $\mathrm{PbO}$ & $\mathrm{B}_{2} \mathrm{O}_{3}$ & $\mathrm{ZnO}$ & CTE & ${ }^{T}$ SOFT & $\begin{array}{l}\text { Devitrification } \\
\text { Temp }\end{array}$ & $\begin{array}{l}\text { Deformation } \\
\text { Point }\end{array}$ & $\begin{array}{l}\text { Soldering } \\
\text { Temp }\end{array}$ \\
\hline $\mathrm{ZnO}$ & + & & & INC & & & DEC & DEC \\
\hline $\mathrm{PbO}$ & & - & + & & & INC & & DEC \\
\hline $\mathrm{B}_{2} \mathrm{O}_{3}$ & + & & - & & & & & DEC \\
\hline $\mathrm{ZnO}$ & $\mathrm{B}_{2} \mathrm{O}_{3}$ & & & DEC & INC & & & \\
\hline $\mathrm{PbO}$ & & $\mathrm{ZnO}$ & & & & DEC & & \\
\hline $\mathrm{ZnO}$ & & $\mathrm{PbO}$ & & & & DEC & & \\
\hline $\mathrm{B}_{2} \mathrm{O}_{3}$ & & & $\mathrm{PbO}$ & & DEC & DEC & & \\
\hline $\mathrm{B}_{2} \mathrm{O}_{3} / \mathrm{ZnO}$ & + & & & INC & & & DEC & \\
\hline $\mathrm{PbO}$ & & - & & INC & & & DEC & \\
\hline
\end{tabular}


4) In Caboal glasses (Ca-B-Aluminates)( $T$ soft $550-794^{\circ} \mathrm{C}$ ), $\mathrm{T}$ soft can be raised by:

$(\mathrm{Al}>\mathrm{Ca})$

a) Replacing $\mathrm{B}_{2} \mathrm{O}_{3}$ by $\mathrm{Al}_{2} \mathrm{O}_{3}$ or $\mathrm{CaO}$

b) Replacing $\mathrm{CaO}$ by $\mathrm{ZrO}_{2}, \mathrm{TiO}_{2}, \mathrm{SiO}_{2}$ $(\mathrm{Si}>\mathrm{Zr}>\mathrm{Ti})$.

$T$ soft can be decreased by:

a) Replacing $\mathrm{CaO}$ by alkalies $(\mathrm{Li}>\mathrm{Na}>\mathrm{K})$.

b) Replacing alkaline earth oxides.

The effect-considerable on viscosity, minimal on CTE - resulting when substitutions were made of a noble-gas-type ion (i.e., $\mathrm{Mg}^{2+}$ ) or a non-noble-gas type $\left(\mathrm{Cu}^{2+}\right)$ in high silica $(67$ mole \%) glasses were reported by Karkhanavala et. $\mathrm{al}^{27}$ These authors followed the approach pioneered by Weyl; ${ }^{61}$ i.e., relating the physical properties of the glass to the polarizability of its ions and their electrical shielding requirements. $\mathrm{Cu}_{2} \mathrm{O}$ is known to reduce the softening temperature in silicate systems.

In the P-Zn-Borate systems, Knapp ${ }^{8}$ reported; (a) Replacing $\mathrm{ZnO}$ by $\mathrm{CdO}$ up to $40 \%$ did not cause devitrification but apparently reduced the melting point, (b) additions of 4 to $10 \% \quad \mathrm{Li}_{2} \mathrm{O}$ increased crystallization and (c) Substituting $\mathrm{ZnF}_{2}$ for $\mathrm{ZnO}$ reduced the devitrification tendency as well as the softening point. The solder glass recommended by $\mathrm{Knapp}$ is $\mathrm{ZnO} 50$ to $30 \%, \mathrm{~B}_{2} \mathrm{O}_{3} 18$ to $20 \%, \mathrm{P}_{2} \mathrm{O}_{5} 16$ to $20 \%, \mathrm{CuO} 14$ to $17 \%, \mathrm{ZrF}_{2} 0$ to $11 \%$, with $\mathrm{T}$ soft 510 to $550^{\circ} \mathrm{C}$ and $\mathrm{CTE} 50 \times 10^{-7} /{ }^{\circ} \mathrm{C}$. Addition of $\mathrm{P}_{2} \mathrm{O}_{5}, \mathrm{SiO}_{2}$ and $\mathrm{Al}_{2} \mathrm{O}_{3}$ to $\mathrm{Pb}-\mathrm{Zn}$-borate glasses was studied extensively by Shirouchi, ${ }^{49}$ whose findings are summarized in Table V. Kruszewski ${ }^{62}$ discusses the effect of dissolved gases in optical glasses.

\subsection{Miscellaneous Solder Glasses}

1.4.1 High elasticity solder glasses. Semenov et. al. ${ }^{63}$ reported strong joints using a soda lime glass to seal two glasses together of varying CTE's (91 and $48 \times 10^{-7} /{ }^{\circ} \mathrm{C}$ respectively). The glass composition recommended was: $\mathrm{SiO}_{2} 27 \%, \mathrm{Al}_{2} \mathrm{O}_{3} 21 \%, \mathrm{~B}_{2} \mathrm{O}_{3}$ $39 \%, \mathrm{Na}_{2} \mathrm{O} 4$ to $2 \%, \mathrm{~K}_{2} \mathrm{O} 1 \%, \mathrm{CaO} 8 \%, \mathrm{MgO} 0$ to $2 \%$, with a CTE 52.6 to $54 \times 10^{-7} /{ }^{\circ} \mathrm{C}$. This solder glass replaced a graded seal between the Russian glasses BD-1 and ZS5 (their compositions are included by Volf). ${ }^{1,2}$ The success of this seal is attributed to the elasticity of the solder glass.

Lap joints that withstood $15,000 \mathrm{psi}$ at room temperature and $3000 \mathrm{psi}$ at $1000^{\circ} \mathrm{C}$ could be made in a metal ceramic system using 60 to $80 \%$ of a sodium-borosilicate glass $\left(\mathrm{Na}_{2} \mathrm{O} 0.5 \%, \mathrm{~B}_{2} \mathrm{O}_{3} 57 \%\right.$, $\mathrm{SiO}_{2} 38 \%$ ) plus 40 to $20 \%$ of a metal powder such as $\mathrm{Cu}, \mathrm{Ni}$ or $\mathrm{Mn} .^{64}$

1.4.2 Vanadate glasses Glasses based on the vanadium oxide system have low melting points but the CTE can vary over a considerable range. A glass with good IR transmission was reported ${ }^{65}$ with a composition of $\mathrm{BaO} 15 \%, \mathrm{TeO}_{2} 31.4 \%$ and $\mathrm{V}_{2} \mathrm{O}_{5}$ $53.6 \%$ having a deformation temperature of $285^{\circ} \mathrm{C}$ and a CTE of $135 \times 10^{-7}$.

Glasses in the composition range $\mathrm{B}_{2} \mathrm{O}_{3} 10$ to $40 \%$, $\mathrm{ZnO} 20$ to $60 \%, \mathrm{~V}_{2} \mathrm{O}_{5} 10$ to $70 \%$ are reported ${ }^{48}$ to have soldering temperatures of $600^{\circ} \mathrm{C}$ and CTE's of 45 to $55 \times 10^{-7}$. Many of the vanadate glasses have poor water resistance, but addition of $\mathrm{PbO}, \mathrm{BaO}$ or $\mathrm{CaO}$ and $\mathrm{Al}_{2} \mathrm{O}_{3}$ up to $5 \%$ does improve their water resistance. These glasses are actually n-type semiconductors.

TABLE V

Effect of composition in $\mathrm{Pb}-\mathrm{Zn}$-borate glass. ${ }^{4}{ }^{9}$

\begin{tabular}{|l|l|l|l|}
\hline \multirow{2}{*}{ Glass Property } & \multicolumn{3}{|c|}{$\begin{array}{c}\text { Effect of Molar Increase in the } \\
\text { Following Components }\end{array}$} \\
\cline { 2 - 4 } & $\mathrm{P}_{2} \mathrm{O}_{5}$ & $\mathrm{Si} \mathrm{O}_{2}$ & $\mathrm{Al}_{2} \mathrm{O}_{3}$ \\
\hline Devitrification & Enhanced & Reduced & Reduced \\
\hline Surface Hardness & Reduced & Enhanced & Enhanced \\
\hline Resistance to $\mathrm{HCl}$ & Enhanced & Enhanced & Enhanced \\
\hline Resistance to $\mathrm{HF}$ & Reduced & Enhanced & Enhanced \\
\hline Resistance to $\mathrm{H} \mathrm{NO} 3$ & Enhanced & Enhanced & Enhanced \\
\hline Deformation Temp & Enhanced & & \\
\hline CTE & none & & \\
\hline Adhesion to Steel & Enhanced & Enhanced & Enhanced \\
\hline
\end{tabular}


1.4.3 Tellurium glasses $\mathrm{TeO}_{2}$ forms a variety of glasses with oxides of $\mathrm{Li}, \mathrm{Na}, \mathrm{B}, \mathrm{Nb}, \mathrm{P}, \mathrm{Mo}, \mathrm{W}, \mathrm{Zn}, \mathrm{V}$, $\mathrm{Mg}, \mathrm{Cd}, \mathrm{Ti}, \mathrm{Ge}, \mathrm{Th}, \mathrm{Ta}, \mathrm{La}, \mathrm{Sb}, \mathrm{Bi}, \mathrm{V}$ and $\mathrm{Pb}$. These varieties are binary or ternary compositions, and are generally characterized by a high refractive index, CTE, density and dielectric constant but a low deformation temperature. ${ }^{66}$

The virtue of the lead tellurides are high densities (4 to $6 \mathrm{~g} / \mathrm{cc}$ ) and a high refractive index (2.199). The zinc-tellurite glasses $\left(\mathrm{TeO}_{2} 65\right.$ to $\left.75 \%\right)$ are reported ${ }^{67}$ to have very low $\tan \delta\left(2.63\right.$ to $\left.4.3 \times 10^{-3}\right)$. These glasses are stable to cold water but attacked by boiling water and dilute acids and alkalies. Additions of $0.5 \% \mathrm{Cu}, 1 \% \mathrm{Nd}_{2} \mathrm{O}_{3}$ or $16 \% \mathrm{Al}_{2} \mathrm{O}_{3}$ if substituted for $\mathrm{ZnO}$ does not change the glass properties to any extent.

\subsubsection{Non-oxide glasses These glasses are based} on ternary systems of As-Tl-S, As-Tl-Se, As-Se$\mathrm{S}$, and $\mathrm{As}-\mathrm{S}-\mathrm{Br}{ }^{69}$ as well as $\mathrm{Ce}-\mathrm{P}-\mathrm{Te}, \mathrm{Ge}-\mathrm{S}-\mathrm{Te}$, $\mathrm{Ge}-\mathrm{Se}-\mathrm{Te}$ and $\mathrm{Ge}-\mathrm{As}-\mathrm{Te}^{66} \mathrm{Umblia}^{58}$ and Cooper ${ }^{66}$ discussed these glasses extensively; the first from the point of view of solder glasses, the latter emphasizing their electronic device applicabilities. These glasses are very poisonous and chemically very unstable. $^{70}$ While as mentioned previously, melting points as low as $100^{\circ} \mathrm{C}$ are observed, their CTE are extremely high $\left(140\right.$ to $\left.420 \times 10^{-7} /{ }^{\circ} \mathrm{C}\right)$ and their electrical resistivities range from $10^{12}$ to $10^{16} \Omega \mathrm{cm}$. This combination of properties does not make them useful solder glasses. Yakhkind ${ }^{71}$ has discussed binary non-oxygen glasses of higher density (4 to 6 $\mathrm{g} / \mathrm{cm}^{3}$ ) and high refracting indices (1.9 to 2.2 ).

\subsubsection{Phosphate glasses These glasses are soluble} even in cold water ${ }^{72}$ and in addition, their CTE's are very high; i.e., 215 to $289 \times 10^{-7} /{ }^{\circ} \mathrm{C}$, though their softening temperature are low $\left(270^{\circ} \mathrm{C}\right)$ for the alkaliphosphates $^{73}$ and for aluminium orthophosphates $\left(\mathrm{CTE}=159 \times 10^{-7} /{ }^{\circ} \mathrm{C}\right.$ with a softening temperature of $\left.330^{\circ} \mathrm{C}\right) .^{74}$ Zinc-borophosphate glasses ( $\mathrm{ZnO} 68.4$ mole $\%, \mathrm{~B}_{2} \mathrm{O}_{3} 22.4$ mole $\%, \mathrm{P}_{2} \mathrm{O}_{5} 9.5$ mole $\%$ ) have a low CTE $\left(50 \times 10^{-7} /{ }^{\circ} \mathrm{C}\right)$ and softening temperature of $579^{\circ} \mathrm{C} . .^{75}$ The chemical stability of these glasses was not improved by the addition of oxides of $\mathrm{Zn}$, $\mathrm{Mg}, \mathrm{Ba}, \mathrm{Cu}, \mathrm{Al}, \mathrm{Ti}, \mathrm{Zr}, \mathrm{Si}$ and $\mathrm{Pb}$.

\subsubsection{IR Absorbing solder glass A Te-V glass was} mentioned previously. Addition of 1 to $8 \%$ of $\mathrm{Cu}$ to a lead-aluminium borosilicate (like Corning 7570 or Pemco QJ207 or XJ208) produces and IR absorbing solder glass compatible with regular lead glasses. ${ }^{76}$ This glass was developed because the usual IR absorbing sealing glasses containing $\mathrm{Fe}$ are not compatible with lead glasses.

1.4.7 Electrically conducting solder glasses The electrical properties have been studied ${ }^{77}$ of glass systems based on the oxides of the transition elements (V, Mo, W, Fe, $\mathrm{Mn}$ and $\mathrm{Ti})$ in various combinations with oxides of alkali, alkaline earth metals, $\mathrm{Si}, \mathrm{P}, \mathrm{B}, \mathrm{Al}$ and $\mathrm{Zn}$. The volume resistivities of these glasses ranged from $10^{9}$ to $10^{13} \Omega \mathrm{cm}$; unfortunately, no other data is furnished. Bartuska ${ }^{78}$ described the formation of a seal by melting an electrically conducting solder glass in the phosphovanadium system in situ by passing a current through the work and solder glass. The conduction mechanism is by electron conduction and the resistivity is a linear function of the vanadium oxide content of the glass.

\subsection{Alternatives to Solder Glasses}

When a suitable glass was not available, other ingenious sealing techniques for glass-to-glass or glassto-metal have been employed. Metal as well as alloy solders have been used to good advantage, because their CTE's can be more easily matched to the workpiece than that of glass. ${ }^{26,79}$ In the case of glasses, thin metal foils can be used or a thin film of metal is predeposited either by sputtering or evaporation on the workpiece. A variety of organic polymers as adhesives of glass joint have been discussed by Escaich. ${ }^{80}$ Lees $^{81}$ made good cryogenic seals by fusing borosilicate glass (CTE $53 \times 10^{-7} /{ }^{\circ} \mathrm{C}$ ) directly to Hafnium (CTE $\times 10^{-7} /{ }^{\circ} \mathrm{C}$ ).

\section{REVIEW OF COMMERCIALLY AVAILABLE SOLDER GLASSES}

The data is this section was compiled from several sources - books, journals, and customer information from vendors. It should be pointed out that most of the commercially-available solder glasses were developed to meet the needs of glass-to-metal sealing. To avoid unwieldy compilations of tables, the information will be organized per source rather than by type of glass.

A considerable amount of data on commercial sealing glasses is compiled in three books referred to frequently in Section 1 but should be repeated here because many of these glasses are identified by the vendors code numbers. 
a) "Handbook of Materials and Techniques for Vacuum Devices," Editor, W. H. Kohl, Chapter 14 on "Glass-to-Metal Seals." In addition to discussing some commercially available GE and Corning solder glasses, it has extensive information on physical data of metals and alloys commonly used in glass-to-metal seals (pp. 400 to 403). Chapter 14 lists 167 references on the subject, though most of them are on glass-tometal seals.

b) "Technical Glasses," by M. B. Volf (1961). Unfortunately, this book is out of print. Chapter 15 is entirely devoted to "Sealing Glasses." Again the glasses are arranged according to the metals to be joined to the glass. This chapter lists the composition, properties and commercial code numbers of 168 solder glasses mostly lead-borosilicates. By far, the majority of these glasses are manufactured by European firms including a number from Russia, CSSR and Poland. Chapter 15 lists 69 references on solder glasses, some of which may no longer be on the market. Because it is impossible to list all the compositions, Table VI summarizes the types of properties and uses of these glasses.

c) "Glass-to-Metal Seals," J. H. Partridge (1967). Table VII lists the physical properties of glasses and metals used in seals including vendor and code number of the glasses. In order to relate the old Corning Code numbers used in the previous tables and sources, Table VIII (Kohl ${ }^{12}$ ) correlates these with the new four-digit Corning glass code.

Subsequent tables are either direct copies or summaries of vendor information both domestic and foreign. These include: (a) Table IX Corning Solder Glasses (b) Table X Listing of Corning and Kimble Glass Codes which are essentially equivalents. (c) Tables XI to XIII, Owens-Illinois (Kimble) Solder Glasses. A comment on these three tables is in order. Kimble has a dual code system. Their glasses are identified by letters plus a digit (i.e., SG-7). However, the preferred computerized order number is an all digit number (in this case 00130). All three tables are reproduced despite some overlap of information. Table XI list those solder glasses especially recommended by the manufacturer for packaging in the electronics industry. Table XII and XIII includes special solder glasses as well, (d) Table XIV lists solder glasses manufactured by the General Electric Co.

Subsequent tables list solder glasses of European manufacturers. All but one of this data comes from

TABLE VI

Summary of Chapter 15 "Sealing Glasses" in Technical Glasses by Volf."

\begin{tabular}{|c|c|c|c|c|c|}
\hline $\begin{array}{l}\text { Seal to } \\
\text { Metal }\end{array}$ & $\begin{array}{l}\alpha \cdot\left(10^{-7}\right) \\
\text { Glass Line } \\
\text { Coefficient } \\
\text { of Thermal } \\
\text { Expansion }\end{array}$ & $\mathrm{Tg}^{\circ} \mathrm{C}$ & $T_{\text {soft }}{ }^{\circ} \mathrm{C}$ & $\begin{array}{l}\text { No. of } \\
\text { Glasses } \\
\text { Listed }\end{array}$ & Type of Glass \\
\hline $\mathrm{Pt}$ & $89-92$ & $504-530$ & & 2 & Lead \\
\hline Dumet & $88-94$ & $425-475$ & $610-630$ & 15 & Lead and Alkali Lime \\
\hline $\begin{array}{l}\text { Envelope of } \\
\text { Incandescent } \\
\text { Lamps }\end{array}$ & 98 & 500 & & 2 & High Silicon with and without Baria \\
\hline $\begin{array}{l}\mathrm{Fe}-\mathrm{Ni}-\mathrm{Cu} \\
\text { Feanico }\end{array}$ & 91 & $400-430$ & $619-700$ & 12 & Lead, Alumino Silictes, Alumino Borosilicates \\
\hline $\mathrm{Fe}-\mathrm{Cu}$ & $90-103$ & $400-588$ & $440-696$ & 28 & Lead and Alkali Limes and Lead Baria \\
\hline $\mathrm{Fe}$ & $112-135$ & & $500-540$ & 25 & Lead Baria, Lithian and Titanion Lead Glasses \\
\hline Housekeeper $\mathrm{Cu}$ & No Limit & & & 1 & Phosphate Glass \\
\hline Mo & $48-52$ & $625-540$ & $700-790$ & 33 & Aluminum Borosilicates \\
\hline Kovar & 43 & $500-560$ & $543-730$ & 25 & Borosilicates and Aluminum Borosilicates \\
\hline w & $36-42$ & $530-770$ & $680-800$ & 25 & Alkali-Alumino - Borosilicates \\
\hline
\end{tabular}


TABLE VII

Glass-to-metal seals (J. H. Partridge; Soc. of Glass Techn. 1967).

\begin{tabular}{|c|c|c|c|c|c|c|c|c|c|c|c|c|c|c|}
\hline $\begin{array}{l}\text { Cimbi- } \\
\text { nition. }\end{array}$ & Mlet:al. & $\begin{array}{l}a \times 10^{\circ} \\
(11 \mathrm{ct}: 11)\end{array}$ & (ilians. & $\begin{array}{l}a \times 10^{0} \\
(1 \text { illusk }) .0\end{array}$ & $\begin{array}{l}\text { Anno } \\
\text { lin } \\
\text { ((ilas }\end{array}$ & & Colour & r of Seal. & \multirow{2}{*}{\multicolumn{2}{|c|}{$\begin{array}{c}\begin{array}{c}\text { State of Strain } \\
\text { (annealed seals } \\
\text { viewed at right } \\
\text { angles to longi- } \\
\text { tudinal axis). }\end{array} \\
\text { Severe compression }\end{array}$}} & $\begin{array}{l}\text { Dia- } \\
\text { meter } \\
\text { of } \\
\text { Wire } \\
(2 a) .\end{array}$ & $\begin{array}{l}\text { Diameter } \\
\text { of } \\
\text { Sheathed } \\
\text { Single } \\
\text { Wire } \\
\text { Real } \\
(2 b) .\end{array}$ & $\begin{array}{l}\text { Ratio } \\
b / a .\end{array}$ & $\begin{array}{l}\text { Maxim } \\
\text { Juns } \\
\text { itm } \\
\text { (aftu } \\
\text { norrm } \\
\text { annegl } \\
\text { (kg./cr }\end{array}$ \\
\hline 1,1 & 'lungstell & $4 \cdot 4$ & ('orning $726 M x$ & $3 \cdot 3$ & $653^{\circ}$ & $510^{\circ}$ & \multicolumn{2}{|c|}{$\begin{array}{l}\text { Straw to light } \\
\text { brown }\end{array}$} & & & $2 \cdot 5$ & 7 & $2 \cdot 8$ & $480 x$ \\
\hline $\begin{array}{l}\text { lh } \\
\text { lic }\end{array}$ & $\ddot{~}$ & ”, & $\begin{array}{l}\text { Pyrex } \\
\text { (arning " Nonex" } \\
(170) 21\end{array}$ & $\begin{array}{l}3 \cdot 2 \\
3 \cdot 6\end{array}$ & isis & $\overline{484}$ & ", & ", & \multicolumn{2}{|c|}{ Gömpression" } & $\begin{array}{l}1 \cdot 0 \\
2 \cdot 5\end{array}$ & $\frac{1 \cdot 1}{7}$ & $\begin{array}{l}4 \cdot 1 \\
2 \cdot 8\end{array}$ & $\begin{array}{l}5201 \\
1271\end{array}$ \\
\hline $1 d$ & $"$ & $"$ & Corning " Viranium" & $1 \cdot 1$ & 635 & 497 & $"$ & $"$ & \multicolumn{2}{|c|}{ Slight compression } & $2 \cdot 5$ & 7 & $2 \cdot 8$ & $48 \mathrm{r}$ \\
\hline $\begin{array}{l}\text { le } \\
\text { if } \\
\text { ly } \\
\text { in }\end{array}$ & ": & ", & $\begin{array}{l}\text { T.W.O. W1 } \\
\text { B.T.H. C9 } \\
\text { H.T.H. C14 } \\
\text { G.E.C. WQ31 }\end{array}$ & $\begin{array}{l}: 3 \cdot 8 \\
3 \cdot 6 \\
3 \cdot 7 \\
1 \cdot 0\end{array}$ & $\begin{array}{l}5601 \\
5: 301 \\
730 \\
-\end{array}$ & $\begin{array}{l}450 \\
460 \\
- \\
-\end{array}$ & Bright & $\begin{array}{c}", \\
-\quad \text { metallic }\end{array}$ & \multicolumn{2}{|c|}{$\begin{array}{l}\text { ", } \\
\text { Strain free } \\
\text { Very severe com- } \\
\text { pression }\end{array}$} & $\begin{array}{l}1.5 \\
1.0 \\
-\end{array}$ & $\begin{array}{l}7 \cdot 3 \\
3 \cdot 0 \\
=\end{array}$ & $\begin{array}{l}4 \cdot 9 \\
3 \cdot 0 \\
- \\
-\end{array}$ & $\begin{array}{l}591 \\
701 \\
- \\
-\end{array}$ \\
\hline $\begin{array}{l}2 a \\
2 b \\
\because \cdots \\
2 . \\
\because .\end{array}$ & $\begin{array}{c}\text { MLolybilenumu } \\
\text { ", } \\
\ddot{"}\end{array}$ & $\begin{array}{l}\mathbf{5} \cdot \mathbf{5} \\
", \\
", \\
, "\end{array}$ & $\begin{array}{l}\text { Gorning 705A.J } \\
\text { Corning (171 } \\
\text { G.F.t. HII } \\
\text { B.T.H.C11 } \\
\text { G.F.O. H26 }\end{array}$ & $\begin{array}{l}4 \cdot 6 \\
5 \cdot 6 \\
4 \cdot 6 \\
4 \cdot 5 \\
4 \cdot: 3\end{array}$ & $\begin{array}{l}496 \\
513 \\
590 \\
585 \\
720\end{array}$ & $\begin{array}{l}461 \\
479 \\
500 \\
500 \\
600\end{array}$ & $\begin{array}{l}\text { Light } \\
\text {," } \\
\text { ", }\end{array}$ & $\begin{array}{l}\text { brown } \\
\text { ", } \\
\text { ", }\end{array}$ & \multicolumn{2}{|c|}{$\begin{array}{l}\text { Severe compression } \\
\text { Slight tension } \\
\text { Compression }\end{array}$} & $\begin{array}{l}2 \cdot 5 \\
2 \cdot 5 \\
1 \cdot 0 \\
1 \cdot 0 \\
1 \cdot 02\end{array}$ & $\begin{array}{l}7 \\
7 \\
3 \cdot 9 \\
3 \cdot 0 \\
3 \cdot 49\end{array}$ & $\begin{array}{l}2 \cdot 8 \\
2 \cdot 8 \\
3 \cdot 9 \\
3 \cdot 0 \\
3 \cdot 4\end{array}$ & $\begin{array}{r}215 r \\
62 r \\
80-5 \\
401 \\
2601\end{array}$ \\
\hline $3 a$ & SPlitinum Substițute & c. $7 \cdot 8$ & G.E.C. L1 & $9 \cdot 1$ & 435 & 350 & Red & & \multicolumn{2}{|c|}{ Severe tension } & 0.8 & $2 \cdot 7$ & $3 \cdot 4$ & $310 \mathrm{c}$ \\
\hline $3 h$ & $\begin{array}{l}\text { Alloy (Copper-coated } \\
43^{\circ} \mathrm{Ni}-\mathrm{Fe} \text { alloy) }\end{array}$ & $\begin{array}{l}\text { longitudinal } \\
\text { c. } 9 \cdot 0 \\
\text { radial }\end{array}$ & B.T.II. C12 & $8 \cdot 7$ & 430 & 360 & \multicolumn{2}{|l|}{ ", } & ", & $"$ & - & - & - & $387 \mathrm{c}$ \\
\hline $\begin{array}{l}4 a \\
4 \prime \prime\end{array}$ & $\begin{array}{l}\text { Platinum } \\
\quad "\end{array}$ & $\begin{array}{l}9 \cdot 4 \\
,\end{array}$ & $\begin{array}{l}\text { G.F.C. X4 } \\
\text { G.E.C. } 11\end{array}$ & $\begin{array}{l}9 \cdot 6 \\
9 \cdot 1\end{array}$ & $\begin{array}{l}520 \\
435\end{array}$ & $\begin{array}{l}450 \\
350\end{array}$ & \multicolumn{2}{|c|}{$\begin{array}{c}\text { Bright metallic } \\
\text { ", }\end{array}$} & \multicolumn{2}{|c|}{ Severe tension } & $\begin{array}{l}2 \cdot 3 \\
0 \cdot 8 \\
0 \cdot 8\end{array}$ & $4 \cdot 1$ & $\begin{array}{l}4 \cdot 1 \\
4 \cdot 1\end{array}$ & $\begin{array}{l}\sin 0 \mathrm{c} \\
\operatorname{stive} \mathrm{c}\end{array}$ \\
\hline $\begin{array}{l}5 a \\
5 b \\
5 c \\
5 d \\
5 e \\
5 f\end{array}$ & $\begin{array}{l}26^{\circ} ; \mathrm{Cr}-\mathrm{Fe} \\
\text { Alloy } \\
\quad " \\
\Rightarrow \\
, "\end{array}$ & $\begin{array}{l}10 \cdot 2 \\
, " \\
", \\
, "\end{array}$ & $\begin{array}{l}\text { Corning G5 } \\
\text { Corning } 66 \\
\text { Corning } 78 \\
\text { "Glass } 286, " \| \\
\text { G.F.C. I14 } \\
\text { B.T.H. C31 }\end{array}$ & $\begin{array}{r}8 \cdot 9 \\
10 \cdot 2 \\
9 \cdot 2 \\
10 \cdot 3 \\
9 \cdot 8 \\
9 \cdot 7\end{array}$ & $\begin{array}{l}\frac{429}{510} \\
\frac{435}{442}\end{array}$ & $\frac{404}{475}$ & $\begin{array}{c}\text { Greeni } \\
\ddot{"}, \\
\ddot{"} \\
\ddot{"}\end{array}$ & $\begin{array}{c}\text { ish grey } \\
\text { ", } \\
\text { ", } \\
\text { ", }\end{array}$ & \multicolumn{2}{|c|}{$\begin{array}{l}\text { Yompression } \\
\text { 'Tension } \\
\text { Compression } \\
\text { Stmain free } \\
\text { Slight compression }\end{array}$} & $\begin{array}{l}2 \cdot 5 \\
2 \cdot 5 \\
2 \cdot 5 \\
1 \cdot \overline{1} \\
-\end{array}$ & $\begin{array}{l}7 \\
7 \\
7 \\
3 \cdot 3 \\
-\end{array}$ & $\begin{array}{l}2 \cdot 8 \\
2 \cdot 8 \\
2 \cdot 8 \\
-3 \cdot 0 \\
-\end{array}$ & $\begin{array}{r}12 \times r \\
126 \mathrm{r} \\
139 \mathrm{r} \\
\text { Alimut } \\
20-61 \\
-\end{array}$ \\
\hline $\begin{array}{l}6 a \\
6 b \\
6 c \\
6 d \\
7 a\end{array}$ & $\begin{array}{l}\text { Fernico I } \\
(54 \% \text { Fe, } 28 \% \text { Ni, } 18 \% \mathrm{Co})\end{array}$ & - & $\begin{array}{l}\text { Corning 705AJ } \\
\text { Corning 705AO } \\
\text { ('orning (171 } \\
\text { "Glass 184" " } \\
\text { Corning 705AO }\end{array}$ & $\begin{array}{l}4 \cdot 6 \\
5 \cdot 0 \\
5 \cdot 0 \\
5 \cdot 0\end{array}$ & $\begin{array}{l}496 \\
495 \\
513 \\
- \\
495\end{array}$ & $\begin{array}{l}461 \\
463 \\
479 \\
463\end{array}$ & $\begin{array}{l}\text { Grey } \\
", \\
\text { Arey }\end{array}$ & & $\begin{array}{l}\text { Comn } \\
\text { Slighit } \\
\quad " \\
\text { stritin }\end{array}$ & $\begin{array}{l}\text { ression } \\
\text { tension } \\
\text { free }\end{array}$ & $\begin{array}{l}2 \cdot 5 \\
2 \cdot 5 \\
2 \cdot 5 \\
2 \cdot 5 \\
2 \cdot 5\end{array}$ & $\begin{array}{l}7 \\
7 \\
7 \\
7 \\
7 \cdot 5\end{array}$ & $\begin{array}{l}2 \cdot 8 \\
2 \cdot 8 \\
2 \cdot 8 \\
2 \cdot 8 \\
3 \cdot 0\end{array}$ & $\begin{array}{r}118 \mathrm{x} \\
52 \mathrm{c} \\
41 \mathrm{C} \\
23 \mathrm{c} \\
\text { Aboui }\end{array}$ \\
\hline $7 b$ & $\begin{array}{l}\text { Fernico II made by powder } \\
\text { metallurgical processes }\end{array}$ & $5 \cdot 1$ & Q.E.C. FCN & $5 \cdot 1$ & 520 & 460 & , & & $"$ & $"$ & $1 \cdot 01$ & $4 \cdot 33$ & $4 \cdot 1$ & About: \\
\hline 8 & $\begin{array}{l}\text { British Kovar type alloys, } \\
\text { e.g." Nicosel," "Telcoseal } \\
\text { No. 1" and "Darwin's } \\
\text { F" alloys }\end{array}$ & $1 \cdot 5$ & G.F.C. FCN & $5 \cdot 1$ & 497 & 440 & , & & \multicolumn{2}{|c|}{ Slight compression } & $2 \cdot 5$ & $3 \cdot 0$ & $2 \cdot 8$ & $\begin{array}{r}0-106 \\
\text { accorc } \\
\text { to met } \\
12 \mathrm{r}\end{array}$ \\
\hline $9 a$ & $\begin{array}{l}\text { Fernichrome }\left(37 \% \% \mathrm{Fe}, 30^{\circ}\right. \\
\mathrm{Ni}, 25 \% \mathrm{Co}, 8 \% \mathrm{Cr})\end{array}$ & $9 \cdot 95$ & Corning (45) & $8 \cdot 9$ & 429 & 401 & $"$ & & \multirow{2}{*}{\multicolumn{2}{|c|}{$\begin{array}{l}\text { Very slight tension } \\
\text { Compression }\end{array}$}} & $2 \cdot 5$ & 7 & $2 \cdot 8$ & $14 \mathrm{cl}$ \\
\hline $9 b$ & & - & Corning G8 & $9 \cdot 2$ & 510 & 475 & , & & & & - & - & $2 \cdot 8$ & $84 \mathrm{rl}$ \\
\hline 10 & $50 / 50 \mathrm{Ni}-\mathrm{Fe}$ alloy & $9 \cdot 5$ & G.E.C. I.1 T & $9 \cdot 1$ & 440 & 350 & , & & \multicolumn{2}{|c|}{ Slight tension } & $1 \cdot 04$ & $3 \cdot 75$ & $3 \cdot 6$ & $34 \mathrm{cl}$ \\
\hline 11 & $\begin{array}{l}\text { Copper-coated } 50 / 50 \mathrm{Ni}-\mathrm{Fe} \\
\text { alloy }\end{array}$ & $9 \cdot 5$ & G.E.o. 1.1 I & $9 \cdot 1$ & 440 & 350 & Rnil & & \multicolumn{2}{|c|}{ Slight compression } & 1.05 & $3 \cdot 28$ & $3 \cdot 2$ & $30 \mathrm{rl}$ \\
\hline 12 & $\begin{array}{l}52 \% \mathrm{Fe}, 42 \% \mathrm{Ni}, 6 \% \mathrm{Cr} \\
\quad \text { alloy }\end{array}$ & $8 \cdot 9$ & G.E.C. I.1 T & $9 \cdot 1$ & 440 & 350 & \multicolumn{2}{|l|}{ (irry } & ", & $"$ & 1.04 & $3 \cdot 9$ & $3 \cdot 8$ & $30 \mathrm{rl}$ \\
\hline 13 & $41 \cdot 5 \% \mathrm{Ni}, 57 \cdot 8 \%$ Fe alloy & - & "Glass $1075 " \|$ & $5 \cdot 3$ & - & - & \multicolumn{2}{|l|}{ ", } & \multicolumn{2}{|c|}{ Strain free } & - & - & - & About \\
\hline $\begin{array}{l}14 a \\
14 b \\
14 c \\
14 d\end{array}$ & $\begin{array}{l}\text { Iron } \\
\text { "”̈ } \\
\text { Copper-plated iron }\end{array}$ & $\begin{array}{l}13 \cdot 2 \\
, " \\
",\end{array}$ & 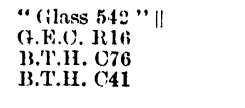 & $\begin{array}{l}13 \cdot 5 \\
11 \cdot 2 \\
11 \cdot 6 \\
12 \cdot 9\end{array}$ & $\bar{E}$ & $\bar{z}$ & \multicolumn{2}{|l|}{ Red } & ", & $\begin{array}{l}\text { ", } \\
\text { ", }\end{array}$ & $\frac{\overline{2 \cdot 02}}{\overline{1 \cdot 0}}$ & $\frac{\overline{6 \cdot 6}}{3 \cdot 0}$ & $\overline{3 \cdot 3}$ & $\begin{array}{r}\text { About } \\
\text { About : } \\
\text { Less t } \\
10 \mathrm{r}\end{array}$ \\
\hline 15 & Copper & $17 \cdot 8$ & $\begin{array}{l}\text { Many glasses if suit- } \\
\text { ably shaped }\end{array}$ & $3 \cdot 5-10 \cdot 2$ & - & - & \multicolumn{2}{|c|}{ Red to gold } & \multicolumn{2}{|c|}{$\begin{array}{l}\text { Strain-free a frac- } \\
\text { tion of millimetre } \\
\text { from joint }\end{array}$} & - & - & - & - \\
\hline
\end{tabular}

rl. signifies in radial direction.

NoTEs.

cl. signifies in circumferential direction.

$a=$ mean coefficient of linear thermal expansion between $20^{\circ}$ and $350^{\circ}$ except Cruing glasses where range is $0-310^{\circ}$.

Values taken from Hull and Buryer's paper.

Values taken from Hull, Burger, and Navias' paper.

\$ Sre list of Corning glasses attached. This, together with thermal expansion data,

II Special glasses made by Dr. Navias. See Table for chemical compositions.

I $\mathrm{C} 12 \mathrm{may}$ also be used for sealing to these metals.

$$
\text { * Annealing Range of Glasses. }
$$

As yet there is no agreed definition of annealing range in terms of the viscosity of the glass. The higher temperature corresponds to the viscosity of about $10^{18.4}$ poises. Specimens of glass become substantially free from strain when heated for 15 minutes nt the temperature corresponding to this viscosity. Specimens 5-7 mm. in diameter become strain-free on heating to this temperature at $2^{\circ}$ per minute. The lower temperature is that corresponding to a viscosity of $10^{16.6}$ poises, in the case of Corning

Corning Gilasses.

$\begin{array}{cl}\text { Code No. } & \text { Glass No. } \\ 774 & \text { 726MX } \\ 772 & \text { G702P } \\ 3320 & 371 \mathrm{BN} \\ 705 & 705 \mathrm{AJ} \\ 771 & \text { G71 } \\ 005 & 155 \\ 013 & \mathbf{9 6} \\ 008 & \text { 48 } \\ 706 & 705 \mathrm{AO}\end{array}$

Composition of Special Sealing Glasses made

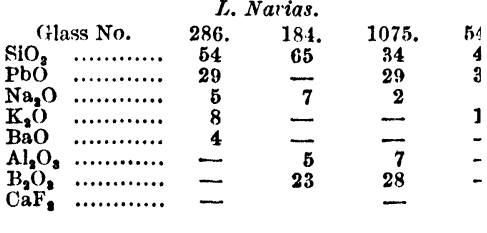


TABLE VIII

Correlation of current four-digit Corning Glass code with obsolete laboratory code numbers. ${ }^{12}$

\begin{tabular}{|c|c|c|c|}
\hline Current & Obsolete & Current & Obsolete \\
\hline$(x) 10$ & $(i-1$ & 7210 & (i-720-1'n \\
\hline $0(014$ & $(i-14$ & $72: 30$ & G-707-Cis-1 \\
\hline 0011 & $(x-4-1)$ & 7210 & $(i-715-10$ \\
\hline $0(1.50$ & $(i-5$ & 7250 & $(x-720-() I$ \\
\hline 00.80 & $G-8$ & 7251 & G-720-WH \\
\hline (6) 41 & $\mathrm{G}-124-\mathrm{HD})$ & 7252 & (X-726-XP \\
\hline 0100 & $G-164-G C$ & 72900 & (i-167-CiL \\
\hline 0110 & $(i-164-11 C$ & 73330 & $(8-7333-A$ \\
\hline 0120 & $\mathrm{G}-12$ & 73331 & (i-10K-PN \\
\hline 0210 & $G-125-1313$ & 7340 & G-733-13 \\
\hline 0250 & $\mathrm{G}-125-\mathrm{AJ}$ & 75010 & (r-750-AH \\
\hline 0280 & G-128-(i & 7510 & (i-750-AI \\
\hline 0281 & $(\mathrm{i}-128-\Lambda \mathrm{Q}$ & 7.520 & $\mathrm{G}-7.50-\mathrm{AJ}$ \\
\hline 1710 & $\mathrm{G}-172-\mathrm{RMI}$ & 75.30 & Ci-805-W \\
\hline 1720 & $(\mathrm{i}-172-\mathrm{AJ}$ & 7550 & $(i-80) 5-(;$ \\
\hline 1723 & $(i-8 x !)-\Lambda b W$ & $756(1)$ & (i. .750$) \mathrm{AL}$ \\
\hline 1910 & $(\mathrm{i}-189-1 Y$ & 7570 & (i-750.(YL \\
\hline 1991 & $(i-18.1 . I Y$ & 7720 & $(i-702-1)$ \\
\hline $2+73$ & $(i-240-P Y$ & 7730 & (i-1752-A \\
\hline 2475 & $(i-210) 1117$ & 7710 & $(i-726-1)) X$ \\
\hline 33320 & $(i-371-13 N$ & 77.11 & $(i-726-) \mathrm{MI}$ \\
\hline 35.30 & $(\mathrm{i}-35) 3-(\mathrm{il})$ & 77.42 & $(i-726-A B H$ \\
\hline 3510 & $(i-35) \%$ & 7750 & $(\mathrm{r}-7() 5-12$ \\
\hline .1320 & $(1-431-\Lambda M$ & 7760 & $(i-720)-(i 0)$ \\
\hline 4107 & $(i-40-1)$ & 7780 & $\left(\right.$ I'I $\left.^{\prime}-70\right)$ \\
\hline 53340 & $(x-5) 3 \cdot 1-A$ & $79(1)(1)$ & $(i-7 !)()-11$ \\
\hline 5120 & $(x-5,12-1)$ & 7910 & $(i-79)(0 . J$ \\
\hline $5 \times 10$ & $(i-570-(i$ & $7 ! 111$ & $(i-79 S-13 E)$ \\
\hline $5 \times 30$ & $\mathrm{G}-570-\Lambda^{\prime} \mathrm{T}$ & $7 ! 112$ & $(x-790)-N$ \\
\hline 5890 & G-5.56-C:K & 7981 & G-707-HN \\
\hline 5911 & G-586-LW & 79991 & G-704-EO \\
\hline 66,11 & G-61-I & 8110 & $(\mathrm{x}-813-13 J$ \\
\hline (69)2 & (i-63-Ak & 8160 & (i-8I4-KW \\
\hline 70)30 & $(i-70) 4-13 A$ & $88(0)$ & $(i-8)$ \\
\hline 7010 & $(i-7) .5 \cdot B \Lambda$ & 88330 & (i-8citi-I) \\
\hline $70: 50$ & $(i-70.5$ A.J & 8870 & $(i-85,8 . V$ \\
\hline 70.51 & $(1.705) F D$ & 8878 & (G-18!) IA \\
\hline$\because 0.72$ & $(\mathrm{~B}-711: 1 . \mathrm{N}$ & 9010 & $(j \cdot 850.5)(1)$ \\
\hline $7(0.5)$ & $(\mathrm{i} .710 \mathrm{HY}$ & 9012 & G.171.1'A \\
\hline 70.50 & $(\mathrm{i}-\times 10 \mathrm{MlF}$ & $97(x)$ & $(i-970 \cdot G$ \\
\hline $7(160$ & $(4-705 \cdot 10)$ & 9720 & (i-970-L \\
\hline 7070 & $(i-707.1) G$ & 0730 & $(i-972-A$ \\
\hline 7120 & $(1-712.0$ & 0740 & (i-870.IIW \\
\hline \multirow[t]{2}{*}{7200} & G-707 Covel & 0741 & (.-970.OF \\
\hline & & 0820 & (i.981-TI \\
\hline
\end{tabular}




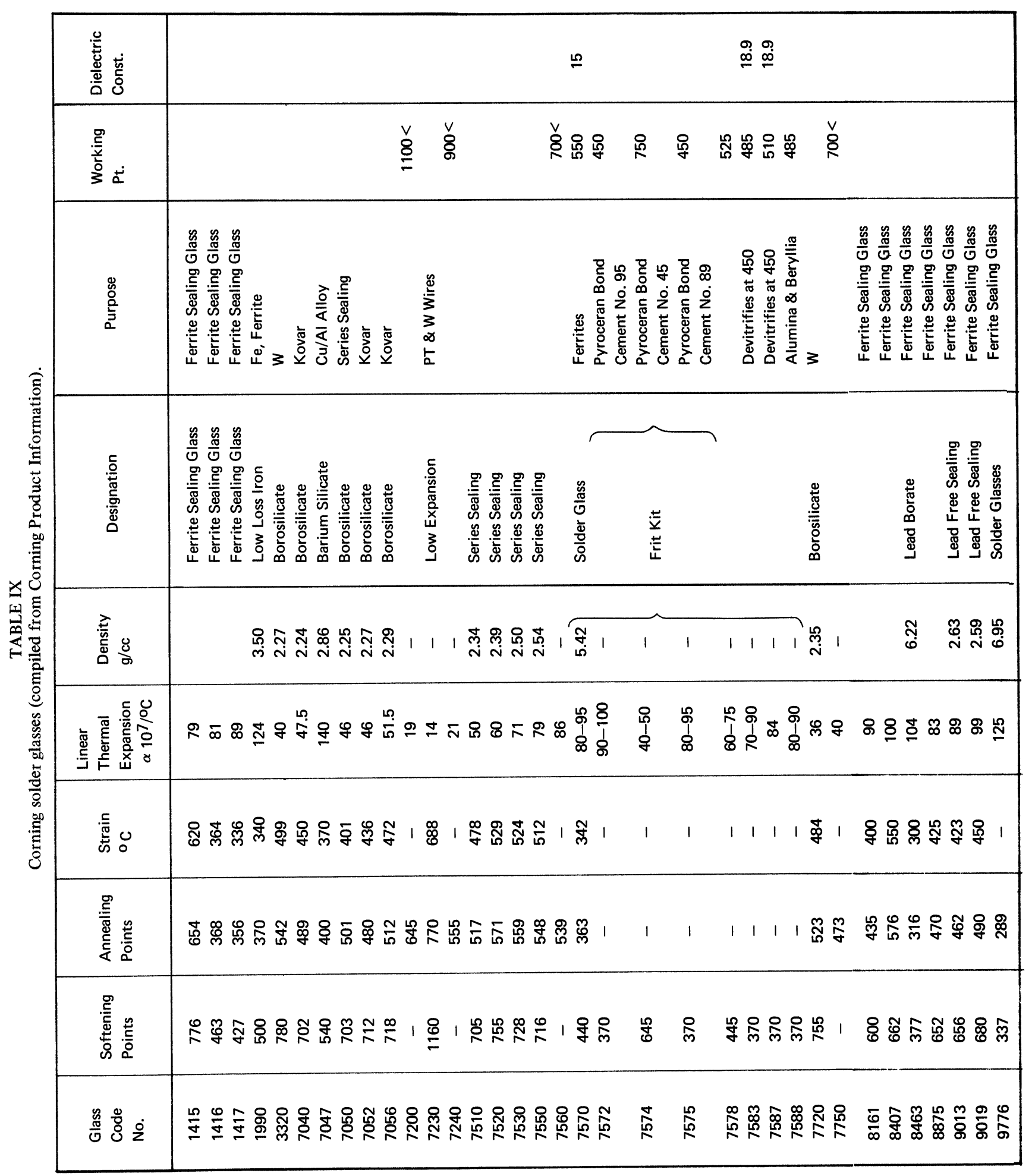


literature sources. These include:

1) Table $X V$

Jenaer Glass works Schott (U.S. Branch release)

2) Tables XVI to XXIV were reproduced from a German publication ( $R$. Kleinteich).

3) Table XVI

4) Table XVII

5) Table XVIII

6) Table XIX

7) Table $X X$

8) Table XXI

9) Table XXII

10) Table XXIII

11) Table XXIV

12) Table XXV

13) Table XXVI

14) Table XXVII

15) Table XXVIII
Solder Glasses Jenaer Glasswerke Schott (German source)

Solder Glasses Glasswerke Wertheim a/Main Solder Glasses Glasswerke Ruhr Essen

Solder Glasses OSRAM Assorted

German Manufactures

Assorted British Manufactures

Solder Glasses Philips Gloelampen Fabrik (Dutch)

Solder Glass Glassworks de Baccaral (France)

Solder Glasses Kavalier Works (CSSR)

Comp. Prop. of Neytrom Glasses (A. Danzin)

Comp. and Prop. of Kavalier Glasses (W. Espe et. al.)

Assorted European Solder Glasses (H. Kalsing)

Assorted European Solder Glass (E. Umblia)
TABLE X

Listing of Corning and Kimble glasses which are essentially equivalent. ${ }^{12}$

\begin{tabular}{|l|l|l|l|}
\hline Kimble & Corning & Kimble & Corning \\
\hline KG-1 & 0010 & K-704 & 7040 \\
KG-12 & 0120 & K-705 & 7050 \\
R-6 & 0080 & ES-1 & 7070 \\
EN-1 & 7052 & IG-1 & 8870 \\
EG-4 & 8871 & IS-8 & 0211 \\
K-772 & 7720 & TH-10 & 0129 \\
KG-33 & 7740 & TL-2 & 9019 \\
EK-3 & 0128 & TM-5 & 9010 \\
EN-3 & 3320 & EZ-1 & 1720 \\
ER-1 & 7761 & N-51-A & 7800 \\
\hline
\end{tabular}


TABLE XI

Physical and chemical properties of sealing glasses $\dagger$ (Owens - Illinois. Recommended for electronics industry).

\begin{tabular}{|c|c|c|c|c|c|c|c|c|c|c|}
\hline \multirow[b]{2}{*}{ Type } & \multirow{2}{*}{$\begin{array}{c}\text { Article } \\
\text { Numbar }\end{array}$} & \multicolumn{2}{|c|}{$\begin{array}{l}\text { Voiume } \\
\text { Resistivity } \\
\text { (ohm-cm) } \\
\text { Expressed as } \\
\text { logarithim of.p }\end{array}$} & \multirow{2}{*}{$\begin{array}{l}\text { Power } \\
\text { Factor } \\
(\Delta \%) \\
\text { At } 25^{\circ} \mathrm{C} \\
\text { and } 1 \mathrm{mc}\end{array}$} & \multirow{2}{*}{$\begin{array}{l}\text { Dielectric } \\
\text { Cunstant } \\
\text { (At } 25^{\circ} \mathrm{C} \\
\text { and } 1 \mathrm{mc} \\
\end{array}$} & \multirow{2}{*}{$\begin{array}{c}\text { Thermal } \\
\text { Excansicn } \\
\text { coefficieat } \\
\times 10^{2} \\
\left(0-30^{\circ} 0^{\circ} \mathrm{C}\right) \\
(\text { per }\end{array}$} & \multirow{2}{*}{ 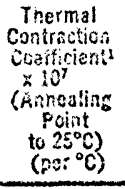 } & \multicolumn{2}{|c|}{ 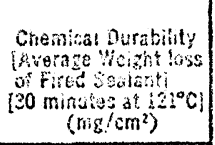 } & \multirow{2}{*}{$\begin{array}{c}\text { Density } \\
(\mathrm{sms} / \mathrm{cc})\end{array}$} \\
\hline & & $250^{\circ} \mathrm{C}$ & $350^{\circ} \mathrm{C}$ & & & & & $\mathrm{H}_{2} \mathrm{O}$ & iviso HC: & \\
\hline $\mathbf{V}$ & $\begin{array}{l}00130 \\
\text { [SG7] }\end{array}$ & 12.4 & 10.5 & 0.80 & 8.2 & 41 & 60 & 0.05 & 5.27 & 4.07 \\
\hline V & $\begin{array}{c}00158 \\
\text { [SG67] }\end{array}$ & 11.1 & 8.9 & 0.15 & 12.5 & 83 & 102 & 0.62 & 3.10 & 5.38 \\
\hline & $\begin{array}{l}00331 \\
\text { [EN1] }\end{array}$ & 9.0 & 7.2 & 0.26 & 5.1 & 47 & 62 & \multicolumn{2}{|c|}{ NEGLIGIELE } & 2.27 \\
\hline & $\begin{array}{l}00338 \\
\text { [IN3] }\end{array}$ & 7.1 & 5.7 & 0.63 & 5.7 & 56 & 70 & \multicolumn{2}{|c|}{ NECLIGIBLE } & 2.32 \\
\hline & $\begin{array}{c}00560^{5} \\
{[\mathrm{CV}-101]}\end{array}$ & 7.6 & 6.4 & 1.5 & 18.5 & 94 & 98 & 1.71 & 7.13 & 6.48 \\
\hline C & $\begin{array}{l}00564^{5} \\
\text { [CV97] }\end{array}$ & 7.8 & 6.4 & 1.3 & 23.8 & 83 & 89 & 2.33 & 6.66 & 6.3 \\
\hline C & $\begin{array}{l}00578^{5} \\
{[C V 102]}\end{array}$ & 6.8 & 5.5 & 1.8 & 24.8 & 108 & 116 & 3.57 & 2.48 & 6.49 \\
\hline & $\begin{array}{l}00583^{5} \\
{[C V 432]}\end{array}$ & 6.6 & 5.0 & $0.0 \hat{6}$ & 27.3 & 117 & 127 & 0.14 & 1.22 & 6.55 \\
\hline & $\begin{array}{c}00756 \\
{[C V 98]}\end{array}$ & 8.3 & 6.7 & 1.6 & 20.6 & 75 & 80 & 2.12 & 7.60 & 6.0 \\
\hline & $\begin{array}{c}00766 \\
{[C V 135]}\end{array}$ & 8.5 & 6.3 & 0.94 & 21.5 & 87 & 95 & 1.98 & 7.60 & 6.05 \\
\hline
\end{tabular}

$\nmid$ Package sealants materials for microelectronics.

${ }^{1}$ For the crystallizing sealants, the contraction coefficient is measured from the recommended holding temperature to $25^{\circ} \mathrm{C}$.

${ }^{2}$ The annealing point and the softening point apply only to the vitreous sealants.

${ }^{3}$ The time and temperature are interrelated. Seals can be made at shorter times by elevating the temperature.

${ }^{4}$ These sealants strongly absorb infrared radiation. Seals can be fabricated in less than one minute with the appropriate infrared source.

${ }^{5}$ These are basic materials that can either be used as supplied or modified by user. The materials to which the resulting product will seal will be determined by the properties of the modified sealant.

${ }^{6}$ These temperatures can be tolerated for up to 10 minutes.

$\mathrm{V}=$ vitreous

$\mathrm{C}=$ crystallizing 
TABLE XI (continued)

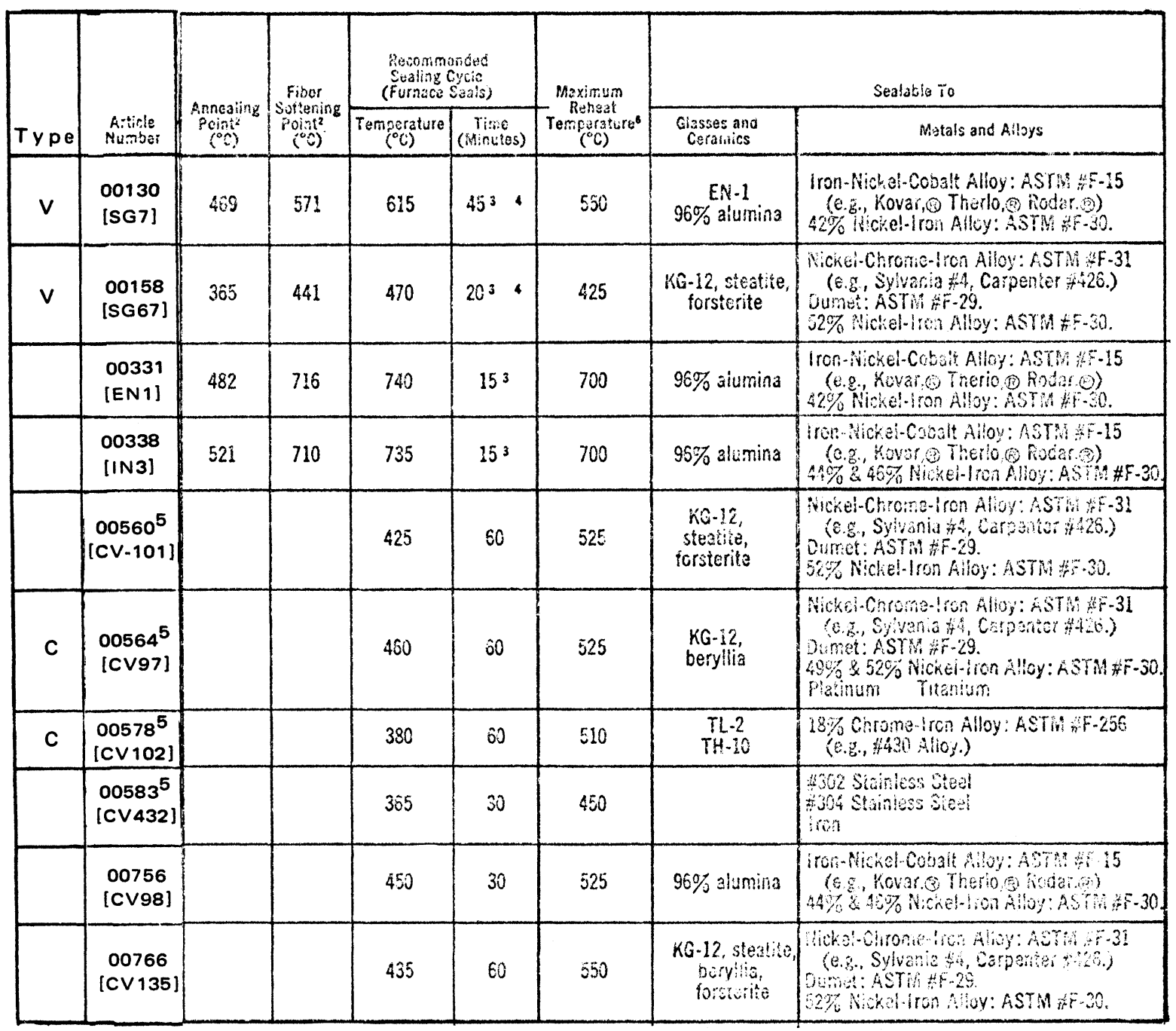


TABLE XIII

Kimble solder glasses - physical properties.

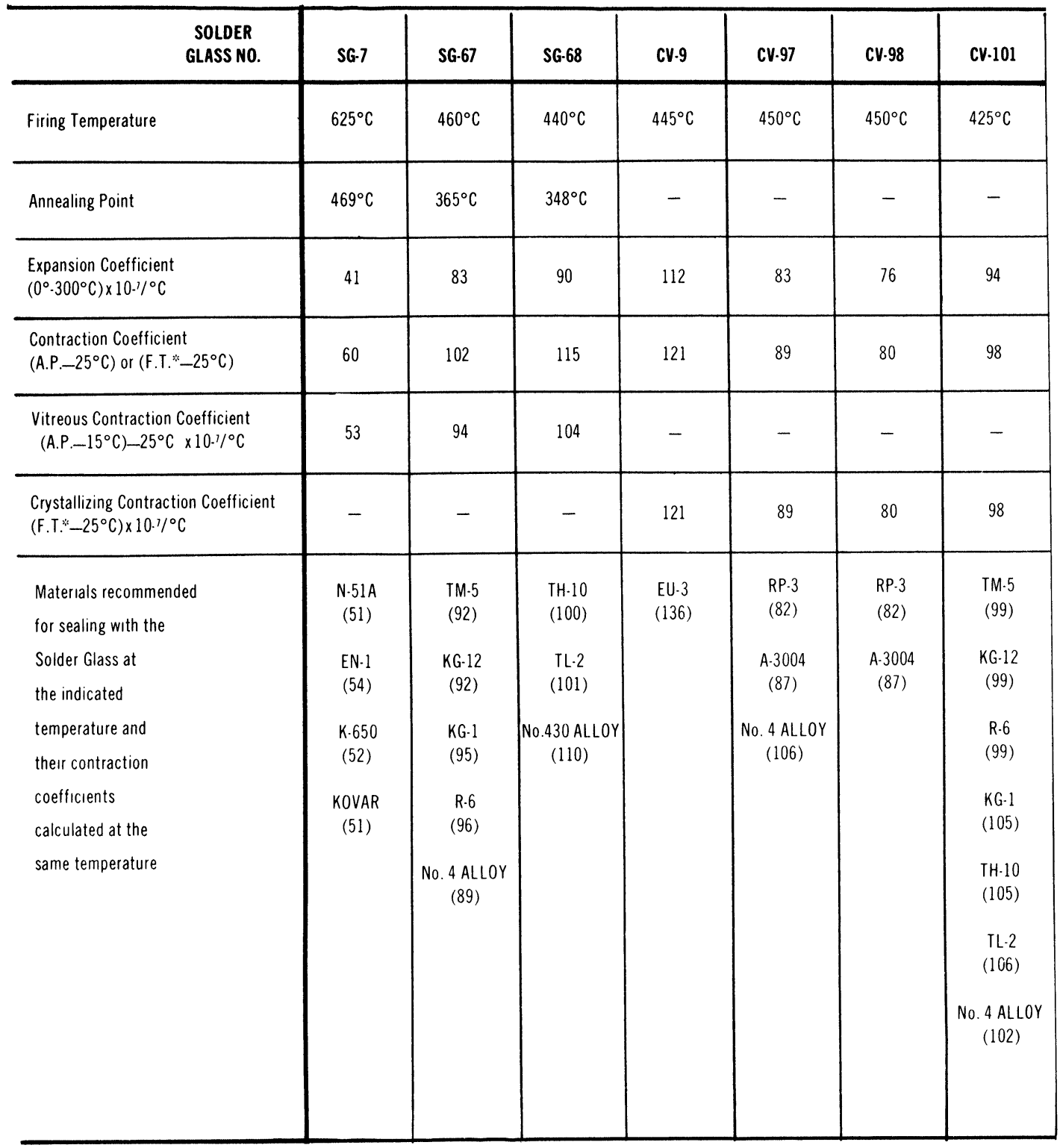


TABLE XIII (continued)

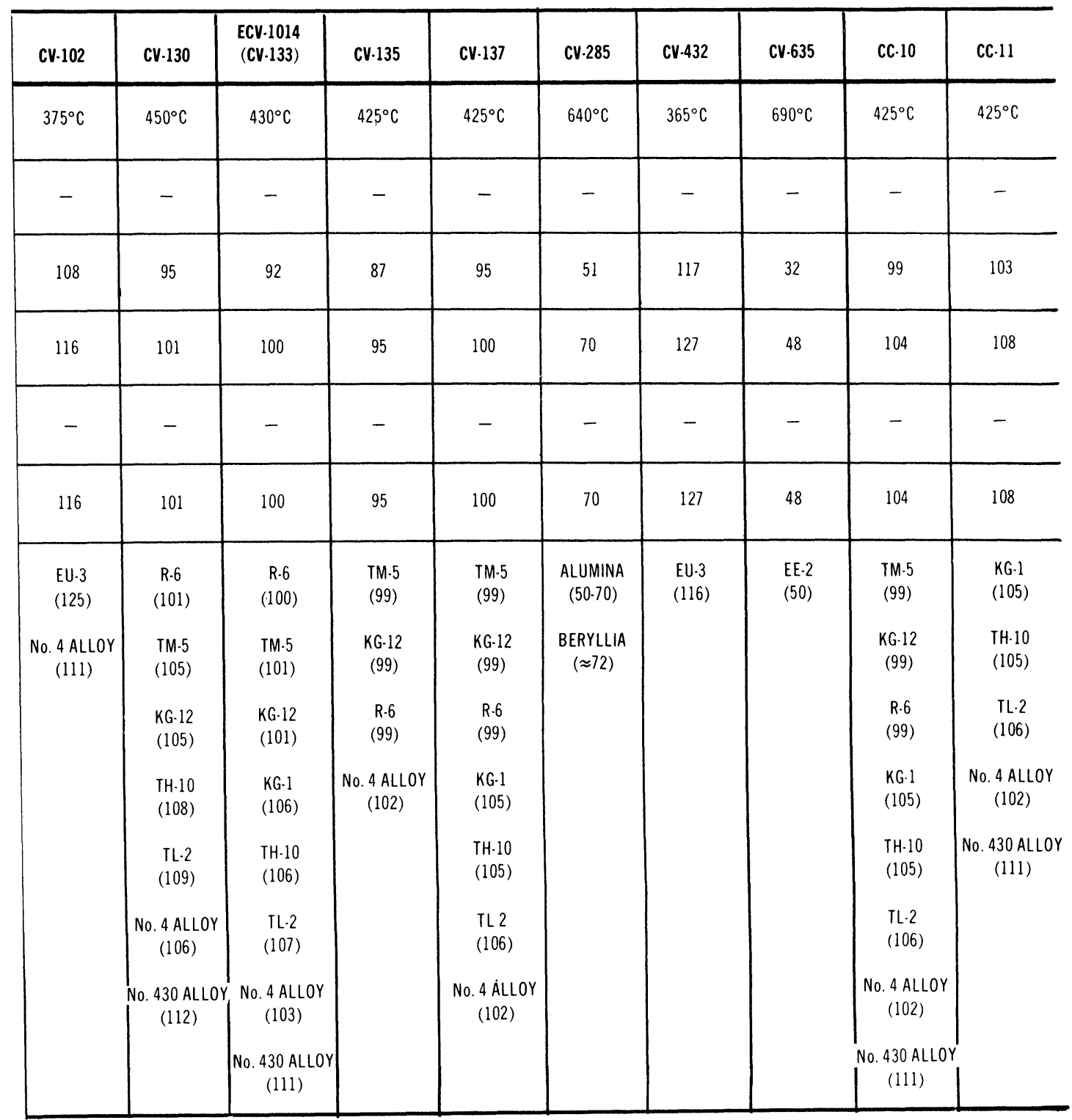


R. G. FRIESER

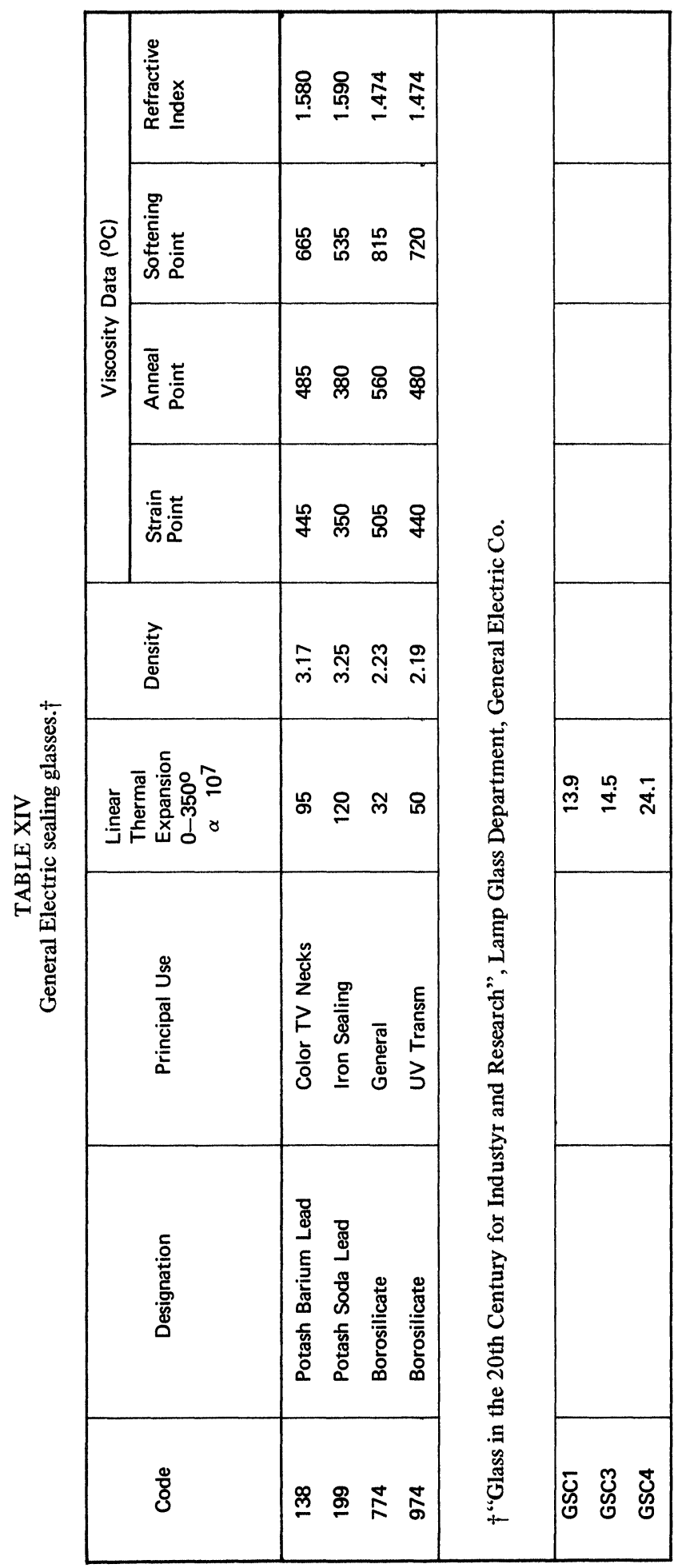


TABLE XV

Physical and chemical properties of industrial glasses (Excerpt from Brochure No. 2051/1E, Jenaer Glasswerke Schott).

\section{Solder Glasses}

\begin{tabular}{|c|c|c|c|c|c|c|c|c|c|c|c|c|}
\hline \multirow{3}{*}{$\begin{array}{l}\text { Glass } \\
\left.\text { No. }{ }^{\dagger}\right)\end{array}$} & \multirow{3}{*}{ Glass type } & \multirow{3}{*}{\begin{tabular}{|c|}
$\begin{array}{c}\text { For soldering } \\
\text { of materials } \\
\text { with }\end{array}$ \\
$\alpha \cdot 10^{7}$ \\
$1 /^{\circ} \mathrm{C}$ \\
\end{tabular}} & \multirow{3}{*}{\begin{tabular}{|c|} 
Soldering \\
tempera- \\
ture after \\
$1 \mathrm{hr}$ sol- \\
dering \\
time ' $)$ \\
\\
\\
\\
${ }^{\circ} \mathrm{C}$ \\
\end{tabular}} & \multirow{3}{*}{\begin{tabular}{|c|}
$\begin{array}{c}\text { Linear } \\
\text { expansion } \\
\text { coefficient }\end{array}$ \\
$\begin{array}{c}\alpha \cdot 10^{7} \\
(20-300 \\
\left.{ }^{\circ} \mathrm{C}\right)\end{array}$ \\
$1 /{ }^{\circ} \mathrm{C}$ \\
\end{tabular}} & \multirow{3}{*}{\begin{tabular}{|c|}
$\begin{array}{c}\text { Transfor- } \\
\text { mation } \\
\text { tempera- } \\
\text { ture }\end{array}$ \\
$\mathrm{Tg}$ \\
${ }^{\circ} \mathrm{C}$ \\
\end{tabular}} & \multicolumn{3}{|c|}{$\begin{array}{c}\text { Temperature at } \\
\text { viscosities (poises) of }\end{array}$} & \multirow{3}{*}{$\begin{array}{l}\text { Density } \\
\mathrm{g} / \mathrm{cm}^{3} \\
\end{array}$} & \multirow{3}{*}{$\begin{array}{l}\text { tk } 100 \\
\\
{ }^{\circ} \mathrm{C} \\
\end{array}$} & \multirow{2}{*}{\begin{tabular}{|l}
$K$ \\
at 1 \\
and
\end{tabular}} & \multirow{3}{*}{$\begin{array}{l}\tan \delta \\
\cdot 10^{4} \\
\\
20^{\circ} \mathrm{C}\end{array}$} \\
\hline & & & & & & $10^{7 \cdot 6}$ & $10^{5}$ & $10^{4}$ & & & & \\
\hline & & & & & & \multicolumn{3}{|c|}{${ }^{\circ} \mathrm{C}$} & & & & \\
\hline 8462 & $\begin{array}{l}\text { Alumo-boro- } \\
\text { silicate glass }\end{array}$ & $60-70$ & 650 & 55 & 429 & 565 & 660 & 737 & 2.31 & 350 & 5.4 & 16.5 \\
\hline 8465 & $\begin{array}{l}\text { Lead borate } \\
\text { glass }\end{array}$ & $85-95$ & 520 & 82 & 385 & 461 & 525 & 566 & 5.38 & 375 & 14.9 & 27 \\
\hline 8467 & $\begin{array}{l}\text { Lead borate } \\
\text { glass }\end{array}$ & $90-105$ & 490 & 91 & 354 & 418 & 487 & 518 & 5.69 & 361 & 15.4 & 29 \\
\hline 8468 & $\begin{array}{l}\text { Lead borate } \\
\text { glass }\end{array}$ & $95-110$ & 450 & 96 & 340 & 405 & 425 & 460 & 5.98 & 333 & 16.3 & 31 \\
\hline 8470 & $\begin{array}{l}\text { Free from lead } \\
\text { borate oxide }\end{array}$ & $105-115$ & 680 & 100 & 439 & 570 & 680 & 748 & 2.84 & 295 & 7.7 & 15.5 \\
\hline 8471 & $\begin{array}{l}\text { Lead borate } \\
\text { glass }\end{array}$ & $110-125$ & 440 & 106 & 332 & 389 & 427 & 456 & 6.23 & 330 & 17 & 32 \\
\hline 8472 & $\begin{array}{l}\text { Lead borate } \\
\text { glass }\end{array}$ & $125-140$ & 410 & 120 & 298 & 360 & 400 & 426 & 6.75 & 281 & 18.2 & 31 \\
\hline 8474 & $\begin{array}{l}\text { Alkali phos- } \\
\text { phate glass }\end{array}$ & $\sim 200$ & 480 & 190 & 326 & 420 & 473 & 512 & 2.56 & 173 & 7.5 & 27 \\
\hline
\end{tabular}

$\dagger$ Reference to previous types: No. 8462 identical with 8435

8465 supersedes 8461 and earlier 8462

8467 supersedes 8461

8470 identical with 8463

8472 supersedes earlier $8468^{2}$ )

${ }^{1}$ Approximate values for unimpeded smooth flowing of solders on glass surfaces.

${ }^{2}$ Previous type No. 8468 is crystallized during soldering; is listed with new No. 8587.

Remarks concerning columns, see main table (inside).

\begin{tabular}{|c|c|c|c|c|c|c|c|c|c|}
\hline \multirow{2}{*}{$\begin{array}{c}\text { Glass } \\
\text { type No. }\end{array}$} & \multirow{2}{*}{$\begin{array}{l}\text { Suitable for } \\
\text { sealing to }\end{array}$} & \multirow{2}{*}{$\begin{array}{c}\alpha \cdot 10^{7} \\
1 /{ }^{\circ} \mathrm{C} \\
(20- \\
\left.300^{\circ} \mathrm{C}\right)\end{array}$} & \multirow{2}{*}{$\begin{array}{l}\mathrm{Tg} \\
{ }^{\circ} \mathrm{C}\end{array}$} & \multicolumn{4}{|c|}{$\begin{array}{c}\text { Temperature of glass in }{ }^{\circ} \mathrm{C} \text { at viscosities } \\
\text { (poises) of }\end{array}$} & \multirow{2}{*}{$\begin{array}{c}d \\
\mathrm{~g} / \mathrm{cm}^{3}\end{array}$} & \multirow{2}{*}{$\begin{array}{l}\text { tk } 100 \\
{ }^{\circ} \mathrm{C}\end{array}$} \\
\hline & & & & $10^{14.5}$ & $10^{13.0}$ & $10^{7 \cdot 6}$ & $10^{4}$ & & \\
\hline 8436 & Sapphire, Vacon 70 & 67 & 620 & 595 & 630 & 810 & 1095 & 2.72 & - \\
\hline 8447 & 2877 - Vacon 10 & 48 & 465 & 437 & 492 & 720 & 1030 & 2.26 & 264 \\
\hline 8448 & $8330-8487$ & 38 & 550 & - & 560 & 807 & 1205 & 2.29 & 235 \\
\hline 8449 & $8486-2877$ & 45 & 520 & 505 & 552 & 780 & 1150 & 2.29 & 330 \\
\hline 8450 & 2877 - KER 220, 2954 & 54 & 568 & - & $5 / 5$ & 778 & 1130 & 2.44 & 200 \\
\hline 8454 & KER 221 - Vacon 70 & 64 & 565 & 540 & 575 & 745 & 1050 & 2.49 & 225 \\
\hline
\end{tabular}

Remarks concerning column 2: Type designation of ceramics is in accordance with German standard DIN 40685 ; Manufacturer of Vacon metal alloys: Vakuumschmelze Hanau (West Germany).

Remarks concerning columns, see main table (inside). 
TABLE XVI

Solder glass of Jenaer Glasswork Schott \& Gen., Mainz. ${ }^{2} 3$

\begin{tabular}{|c|c|c|c|c|c|c|}
\hline \multirow[t]{2}{*}{$\begin{array}{l}\text { Code } \\
\text { Glass } \\
\text { No. }\end{array}$} & \multirow[t]{2}{*}{ Glass Type } & \multicolumn{2}{|c|}{$\begin{array}{l}\text { Coefficient of } \\
\text { Thermal Expan. } \\
\propto(10-7 / 0 \mathrm{C})\end{array}$} & \multirow[t]{2}{*}{$\begin{array}{l}\mathrm{Tg} \\
{ }^{\circ} \mathrm{C}\end{array}$} & \multirow[t]{2}{*}{$\begin{array}{l}T_{\text {soft }} \\
{ }^{\circ} \mathrm{C}\end{array}$} & \multirow[t]{2}{*}{ Sealable To } \\
\hline & & $0-100^{\circ} \mathrm{C}$ & $20-300^{\circ} \mathrm{C}$ & & & \\
\hline 8330 & Duran 50 & 32 & 32 & 530 & 815 & Tungsten \\
\hline 2955 & Supremax & 33 & 37 & 715 & 938 & Tungsten \\
\hline 8409 & Supremax 56 & 37 & 41 & 745 & 960 & Tungsten \\
\hline 3891 & Suprax & 39 & 40 & 553 & 793 & Tungsten \\
\hline 8212 & Wolframglas & 40 & 41 & 495 & 742 & Tungsten \\
\hline 1646 & Wolframglas & 41 & 42 & 515 & 754 & Tungsten \\
\hline 8447 & $\begin{array}{l}\text { Mo-Glas \& for } \\
\text { Fe-Ni-Co-Leg. }\end{array}$ & 47 & 48 & 465 & 720 & Moly u. Fe-Ni-Co-Alloys \\
\hline 2877 & Geräteglas G 20 & 48 & 49 & 560 & 794 & Moly \\
\hline 8412 & Fiolax, klar & 48 & 49 & 558 & 783 & \\
\hline 1639 & Mo-Glass & 49 & 50 & 531 & 736 & Moly \\
\hline 8243 & Mo-Glass and for & 50 & 52 & 485 & 715 & Moly, Vacon 10 \\
\hline 1447 & Fe-Ni-Co-Leg. & 50 & 51 & 528 & 725 & $\begin{array}{l}\text { Moly, Vacon } 12 \text {, } \\
\text { Kovar, } \mathrm{Cu}\end{array}$ \\
\hline 2954 & Thermometerglass & 60 & 64 & 590 & 780 & Vacon 20, Kovar \\
\hline $16 \mathrm{III}$ & Normalglass & 82 & 90 & 543 & 712 & Pt, Cu-Sleeve, Vacovit 501 and 511 \\
\hline 8196 & FS-Kolbenglass & 86 & 94 & 437 & 660 & Pt, Vacovit 485 and 426 \\
\hline 8095 & Bleiglass & 88 & 95 & 425 & 628 & $\begin{array}{l}\text { Pd, Pt and Pt-Cu-Sleeve } \\
\text { Vacovit } 485 \text { and } 426\end{array}$ \\
\hline 8405 & Uviolglass & 92 & 97 & 440 & 657 & Pt, Pt-Cu, Vacovit 485 u. 426 \\
\hline 4210 & Eisenglass & 116 & 127 & 445 & 614 & Iron \\
\hline
\end{tabular}


TABLE XVII

Solder glasses of Glaswerk Wertheim, Wertheim am Main. ${ }^{2}$

\begin{tabular}{|c|c|c|c|c|c|c|}
\hline \multirow[t]{2}{*}{ Glass Type } & & \multicolumn{2}{|c|}{$\begin{array}{c}\text { CTE } \\
\propto\left(10^{-7} / \mathrm{O}^{\mathrm{C}}\right)\end{array}$} & \multirow{2}{*}{$\begin{array}{l}\mathrm{Tg} \\
\mathrm{O}_{\mathrm{C}}\end{array}$} & \multirow{2}{*}{$\begin{array}{l}T_{\text {soft }} \\
{ }^{\circ} \mathrm{C}\end{array}$} & \multirow{2}{*}{ Sealable To } \\
\hline & & $20-100^{\circ} \mathrm{C}$ & $20-400^{\circ} \mathrm{C}$ & & & \\
\hline Mo-Glass & EW & 42 & 44 & 505 & 565 & Moly, Kovar \\
\hline Resistenzglass & $\mathbf{R}$ & 57 & 63 & 570 & 620 & Vacon $10,12,20$ \\
\hline Geräteglass & S & 72 & 81 & 530 & 590 & \\
\hline Normalglass & NW & 80 & 89 & 540 & 600 & Pt, Pt-Cu-Sleeve, Vacovit 501 \\
\hline Geräteglass & GW & 87 & $\sim 95$ & 525 & 580 & Pt, Pt-Cu-Sleeve, Vacovit 501, 511 \\
\hline Einschmelzglass & KW & 86 & 102 & 545 & 595 & Pt, Pt-Cu-Sleeve, Vacovit 511, 540 \\
\hline Einschmelzglass & LW & 88 & 97 & 520 & 570 & Pt, Pt-Cu-Sleeve, Vacovit 426, 511,540 \\
\hline Leuchtröhrenglass & & 88 & 97 & 500 & 550 & \\
\hline Einschmelzglass & MW & 89 & 99 & 420 & 460 & Pt, Pt-Cu-Sleeve, Vacovit 426 \\
\hline Apparateglass & AW & 90 & 100 & 505 & 570 & Pt, Pt-Sleeve, Pd \\
\hline
\end{tabular}

TABLE XVIII

Solder glasses, Glaswerke Ruhr, Essen. ${ }^{23}$

\begin{tabular}{|c|c|c|c|c|c|}
\hline & \multicolumn{2}{|c|}{$\begin{array}{c}\text { CTE } \\
\propto\left(10^{-7} / 0^{\circ} \mathrm{C}\right)\end{array}$} & \multirow{2}{*}{$\begin{array}{l}\mathrm{Tg} \\
\circ \mathrm{C}\end{array}$} & \multirow{2}{*}{$\begin{array}{l}T_{\text {soft }} \\
{ }^{\circ} \mathrm{C}\end{array}$} & \multirow{2}{*}{ Sealable To } \\
\hline & $0-100^{\circ} \mathrm{C}$ & $20-300^{\circ} \mathrm{C}$ & & & \\
\hline AR-Glass & 91 & 95 & 520 & $\sim 718$ & Pt, Pt-Sleeve, Vacovit 501 \\
\hline ARN-Glass & $\sim 78$ & $\sim 80$ & 525 & $\sim 720$ & Pt, Pt-Cu-Sleeve \\
\hline LR-weiss & 107 & 110 & 479 & $\sim 660$ & Pt, Pd, Pt-Sleeve, Vacovit 025 \\
\hline LR-braun & 106 & 109 & 492 & $\sim 671$ & \\
\hline MGR-Glass & 101 & 105 & 484 & $\sim 671$ & Pt, Pt-Cu-Sleeve, Pd, Vacovit 426 \\
\hline
\end{tabular}

TABLE XIX

Solder glasses Osram GMBH. Munchen/Augsburg. ${ }^{2} 3$

\begin{tabular}{|c|c|c|c|c|c|}
\hline \multirow[t]{2}{*}{ Glass Type } & \multicolumn{2}{|c|}{$\begin{array}{c}\text { CTE } \\
\propto\left(10^{-7} /{ }^{\circ} \mathrm{C}\right)\end{array}$} & \multirow{2}{*}{$\begin{array}{l}\mathrm{Tg} \\
\circ \mathrm{C}\end{array}$} & \multirow{2}{*}{$\begin{array}{l}T_{\text {soft }} \\
{ }^{\circ} \mathrm{C}\end{array}$} & \multirow[t]{2}{*}{ Seal To } \\
\hline & $0-150^{\circ} \mathrm{C}$ & $0-300^{\circ} \mathrm{C}$ & & & \\
\hline Tube Glass $905 \mathrm{c}$ & 91 & 102 & 500 & 740 & Pt, Pt-Sleeve, Vacovit 501 \\
\hline Solder Glass 123a & 88 & 97 & 415 & 682 & Pt;Cu-Sleeve, Vacovit 501 \\
\hline Solder Glass 301b & 91 & 96 & 460 & 688 & Pt, Pt-Cu-Sleeve, Vacovit 501 \\
\hline Solder Glass $911 \mathrm{~b}$ & 49 & 53 & 500 & 752 & Mo, Kovar, Vacon 12 \\
\hline Solder Glass $919 \mathrm{c}$ & 50 & 54 & 500 & 744 & Mo, Kovar, Vacon 12 und 10 \\
\hline Solder Glass $906 c$ & 45 & 49 & 508 & 770 & Molybdenum \\
\hline Solder Glass $362 a$ & 41 & 42 & 480 & 820 & Tungsten \\
\hline
\end{tabular}


TABLE XX

Assorted other German manufactures. ${ }^{2}$

\begin{tabular}{|c|c|c|c|c|c|c|}
\hline \multirow{2}{*}{ Glass Type } & \multicolumn{2}{|c|}{$\begin{array}{c}\text { CTE } \\
\propto\left(10^{-7} / 0^{\circ} \mathrm{C}\right)\end{array}$} & \multirow{2}{*}{$\begin{array}{l}\mathrm{Tg} \\
\circ \mathrm{C}\end{array}$} & \multirow{2}{*}{$\begin{array}{l}T_{\text {soft }} \\
0_{\mathrm{C}}\end{array}$} & \multirow{2}{*}{ Manufact. } & \multirow{2}{*}{ Seal To } \\
\hline & $20-100^{\circ} \mathrm{C}$ & $20-300^{\circ} \mathrm{C}$ & & & & \\
\hline Silibor & 8 & & 1000 & & $\mathrm{~S}$ & Sealing Glass \\
\hline Rasotherm Glass & 31 & 33 & 554 & 621 & $\mathrm{~S}$ & Tungsten \\
\hline Wolframe Glass $1646 \mathrm{III}$ & 41 & 45 & 540 & 600 & $\mathrm{~S}$ & Tungsten \\
\hline Apparatus Glass & 46 & 48 & 558 & 608 & $\mathrm{~S}$ & Molybdenum \\
\hline Molybd Glass 1639 III & 46 & 48 & 532 & 570 & $\mathrm{~s}$ & Molybdenum, Vacon 10 \\
\hline Molyb Glass 1447 III & 50 & 55 & 533 & 570 & s & Molybdenum, Vacon 12 \\
\hline Therm-Glass 2954 III & 58 & 65 & 593 & 629 & $\mathrm{~s}$ & Kovar, Vacon \\
\hline Normal Glass 16 III & 80 & 84 & 550 & 589 & s & Pt, Pt-Cu-Sleeve, Vacovit 511 \\
\hline Solder Glass 3079 III & 81 & 94 & 481 & 525 & s & Pt, Pt-Cu-Sleeve \\
\hline Platinun Glass 2962 III & 80 & 90 & 518 & 560 & $\mathrm{~s}$ & Pt, Pt-Sleeve, Pd, Vacovit 501, 511 \\
\hline Fisher-prima & 85 & 92 & 518 & 547 & $\mathrm{~F}$ & Pt, Pt-Cu-Sleeve, Vacovit 501 \\
\hline Gege-Eff & 76 & 84 & 535 & 581 & $F$ & Pt-Cu-Sleeve, Vacovit 501 \\
\hline Iron Glass & 109 & 125 & 474 & 520 & $F$ & Pure Iron \\
\hline Special Glass 357 & 67 & & 544 & 593 & $\mathrm{~F}$ & Kovar \\
\hline X-Glass & 95 & 103 & 503 & 540 & $F$ & Cu-Ring und Pd \\
\hline Molybd Glass 637a & 46 & 47 & 587 & 630 & 0 & Molybdenum \\
\hline Glass 362a & 39 & 40 & 553 & 592 & 0 & Tungsten \\
\hline A-Glass & 67 & 70 & 568 & 610 & J & \\
\hline Lead Glass & 87 & 96 & 443 & 484 & $\mathrm{~J}$ & Pt-Cu-Sleeve \\
\hline N-Glass & 82 & 90 & 537 & 578 & $J$ & Pt, Pt-Cu-Sleeve, Vacovit 501 \\
\hline
\end{tabular}

Manufactures

$\mathrm{S}=$ Saale-Glas GmbH, Jena.

$\mathrm{F}=$ VEB Glaswerk Gustav Fischer, Ilmenau.

$\mathrm{O}=$ VEB Osram, Weisswasser.

$\mathbf{J}=$ VEB Westglaswerke, Ilmenau. 
TABLE XXI

British solder glasses. ${ }^{23}$

\begin{tabular}{|c|c|c|c|c|c|}
\hline Glass Code & $\begin{array}{c}\text { CTE } \\
\left(10^{-7 / 0} \mathrm{C}\right) \\
0-300^{\circ} \mathrm{C}\end{array}$ & $\begin{array}{l}\mathrm{T}_{\text {an }} \\
\circ \mathrm{C}\end{array}$ & $\begin{array}{r}T_{\text {soft }} \\
{ }^{\circ} \mathrm{C}\end{array}$ & Manufact. & Seal To \\
\hline Dial 36 & 36 & 580 & & PT & Tungsten \\
\hline Bluesil & 37 & 570 & & PT & Tungsten \\
\hline Kodial & 49 & 535 & & PT & Moly, Kovar \\
\hline Normal & 84 & 560 & & PT & Ni-Fe-Alloy \\
\hline Dial 444 & 88 & 510 & & PT & Pt, Pt-Cu-Sleeve \\
\hline Neon Soda & 96 & 520 & & PT & Pt, Pt-Sleeve, Fe-Cr-Alloy \\
\hline C 9 & 36 & 525 & 775 & BT & Tungsten \\
\hline C 11 & 45 & 575 & 795 & BT & Moly \\
\hline C 46 & 43 & 775 & 840 & BT & Moly \\
\hline C 40 & 48 & 505 & 710 & BT & Kovar, Vacon \\
\hline C 41 & 128 & 540 & 620 & BT & Iron \\
\hline C 12 & 90 & 435 & 630 & BT & Pt, Pt-Sleeve, Ni-Fe-Alloy \\
\hline GH 1 Hysil & 35 & 556 & 780 & $\mathrm{CH}$ & Tungsten \\
\hline GS 1 Intasil & 38 & 600 & & $\mathrm{CH}$ & Tungsten \\
\hline GS 4 & 44 & 610 & & $\mathrm{CH}$ & Moly \\
\hline GSB & 52 & 450 & 715 & $\mathrm{CH}$ & Kovar, Nilo \\
\hline GWB & 100 & 400 & 610 & $\mathrm{CH}$ & Pt, Pt-Sleeve, Fe-Cr-Alloy \\
\hline $\mathrm{FCN}$ & 48 & 480 & 680 & $\overline{G E}$ & Kovar, Nilo \\
\hline w 1 & 37 & 580 & 760 & GE & Tungsten \\
\hline $\mathrm{HH}$ & 46 & 590 & 780 & GE & Moly \\
\hline M 6 & 73 & 580 & 600 & GE & \\
\hline L 1 & 90 & 430 & 610 & GE & Pt, Pt-Cu-Moly,Ni-Fe-Alloy \\
\hline
\end{tabular}

\footnotetext{
Manufactures

PT = Plowden \& Thompson Limited, Stourbridge

BT = British Tomson, Houston

$\mathrm{CH}=$ Chance Brothers

$\mathrm{GE}=$ Gen. Electric Co, Wembley
} 
TABLE XXII

Dutch solder glasses Philips-Gloelampen Fabrik. ${ }^{2}$

\begin{tabular}{|c|c|c|c|c|}
\hline $\begin{array}{l}\text { Glass } \\
\text { Code }\end{array}$ & $\begin{array}{c}\text { CTE } \\
\alpha\left(10^{-7} /{ }^{\circ} \mathrm{C}\right) \\
0-300^{\circ} \mathrm{C}\end{array}$ & $\begin{array}{l}T_{\text {an }} \\
\circ \mathrm{C}\end{array}$ & $\begin{array}{l}T_{\text {soft }} \\
{ }^{\circ} \mathrm{C}\end{array}$ & Seal To \\
\hline 08 & 39 & 550 & 770 & Tungsten \\
\hline 18 & 38 & 740 & 955 & Tungsten \\
\hline 28 & 48 & 495 & 720 & Moly, Kovar \\
\hline 158 & 50 & 515 & 706 & Moly, Kovar \\
\hline 01 & 92 & 425 & 620 & $\begin{array}{l}\text { Pt, Pt-Sleeve } \\
\text { Ni-Fe-Alloy }\end{array}$ \\
\hline 143 & 96,5 & 485 & 685 & $\begin{array}{l}\text { Pt, Pt-Sleeve } \\
\text { Ni-Fe-Alloy }\end{array}$ \\
\hline
\end{tabular}

TABLE XXIII

French solder glass of Cristallerie de Baccaral. ${ }^{23}$

\begin{tabular}{|l|c|c|l|}
\hline Glass Code & $\begin{array}{c}\text { CTE } \\
\times\left(10^{-7 / 0} \mathrm{C}\right) \\
20-100^{\circ} \mathrm{C}\end{array}$ & $\begin{array}{c}\mathrm{Tg} \\
{ }^{\circ} \mathrm{C}\end{array}$ & Seal To \\
\hline E- Neutrohm & 49 & 510 & Moly, Kovar \\
T- Neutrohm & 35 & 540 & Tungsten \\
P. Neutrohm & 50 & 560 & Moly \\
\hline
\end{tabular}

TABLE XXIV

Czechoslovak solder glass of Kavalier-Glaswerke. ${ }^{23}$

\begin{tabular}{|l|c|c|l|l|}
\hline Glass Code & $\begin{array}{c}\text { CTE } \\
\alpha\left(10^{-7} / \mathrm{O} \mathrm{C}\right)\end{array}$ & $\begin{array}{c}\mathrm{Tg} \\
{ }^{\circ} \mathrm{C}\end{array}$ & $\begin{array}{c}\mathrm{T}_{\text {defor }} \\
{ }^{\circ} \mathrm{C}\end{array}$ & Seal To \\
\hline $\begin{array}{l}\text { Wolframglas } \\
\text { WoKa }\end{array}$ & 40 & 483 & 575 & Tungsten \\
Kovarglas K705 & 47 & 465 & 540 & Kovar, Moly \\
Moly & 50 & 550 & 605 & Moly \\
MoKa & 87 & 530 & 560 & N-Fe-Alloy \\
D 47 & 31 & 490 & 590 & Tungsten \\
SIMAX & 32 & 480 & 575 & Tungsten \\
LL (K707) & & &
\end{tabular}

TABLE XXV

Composition and properties of Neutrohm Glass. ${ }^{23}$

\begin{tabular}{|l|c|c|c|}
\hline & Neutrohm T & Neutrohm E & Neutrohm P \\
\hline $\mathrm{SiO}_{2}$ & 52,4 & 50 & 54 \\
$\mathrm{Na}_{2} \mathrm{O}$ & 0,7 & 1,8 & 0,7 \\
$\mathrm{Al}_{2} \mathrm{O}_{3}$ & 5 & 5 & 5 \\
$\mathrm{MgO}$ & 1 & 1 & 1 \\
$\mathrm{ZnO}$ & 2,5 & 1 & 2,5 \\
$\mathrm{PbO}$ & 29 & 28,7 & 12 \\
$\mathrm{BaO}$ & - & - & 10,5 \\
$\mathrm{~B}_{2} \mathrm{O}_{3}$ & 8,5 & 12 & 8 \\
$\mathrm{As} 2 \mathrm{O}_{3}$ & 0,6 & 0,5 & 0,5 \\
$\mathrm{CaO}$ & - & - & 6 \\
$\mathrm{~T}_{\text {an }}{ }^{\circ} \mathrm{C}$ & 540 & 510 & 560 \\
$\mathrm{~T}_{\mathrm{K}} 100$ & 355 & 322 & 340 \\
Solubility & $8 \mathrm{mg}$ & $8 \mathrm{mg}$ & - \\
Index & & & \\
(German & & & \\
Powder & & & \\
Method) & & & \\
\hline
\end{tabular}

TABLE XXVI

Composition and properties of Czechslovak solder glasses. ${ }^{80}$

\begin{tabular}{|l|c|c|c|c|}
\hline \multirow{2}{*}{ Comp. Wt \% } & \multicolumn{4}{|c|}{ Glass Type } \\
\cline { 2 - 5 } & $\mathrm{K} 707$ & WoKa & MoKa & $\mathrm{K} 705$ \\
\hline $\mathrm{SiO}_{2}$ & 72,8 & 70 & 75 & 66 \\
$\mathrm{~B}_{2} \mathrm{O}_{3}$ & 22,3 & 14,5 & 10 & 21 \\
$\mathrm{PbO} \mathrm{n}$ & 5,5 & & \\
$\mathrm{Al}_{2} \mathrm{O}_{3}$ & 1,1 & 4,8 & 4,9 & 4,8 \\
$\mathrm{Na}_{2} \mathrm{O}$ & 1,5 & 1,3 & 7,2 & 3 \\
$\mathrm{~K}_{2} \mathrm{O}$ & 1,2 & 3,2 & 1,3 & 4 \\
$\mathrm{CaO}$ & 0,8 & 1,8 & 1,6 & \\
$\mathrm{Li}_{2} \mathrm{O}$ & 0,2 & & & \\
$\mathrm{As} 2 \mathrm{O}_{3}$ & & & & \\
$\mathrm{~F}$ & Trace & & & \\
$\mathrm{Cl}$ & & & & \\
$\mathrm{CTE}$ & & & & \\
$\alpha\left(20-300^{\circ} \mathrm{C}\right)$ & $33,4 \cdot 10^{-7}$ & $40 \cdot 10^{-7}$ & $50 \cdot 10^{-7}$ & $47 \cdot 10^{-7}$ \\
\hline
\end{tabular}




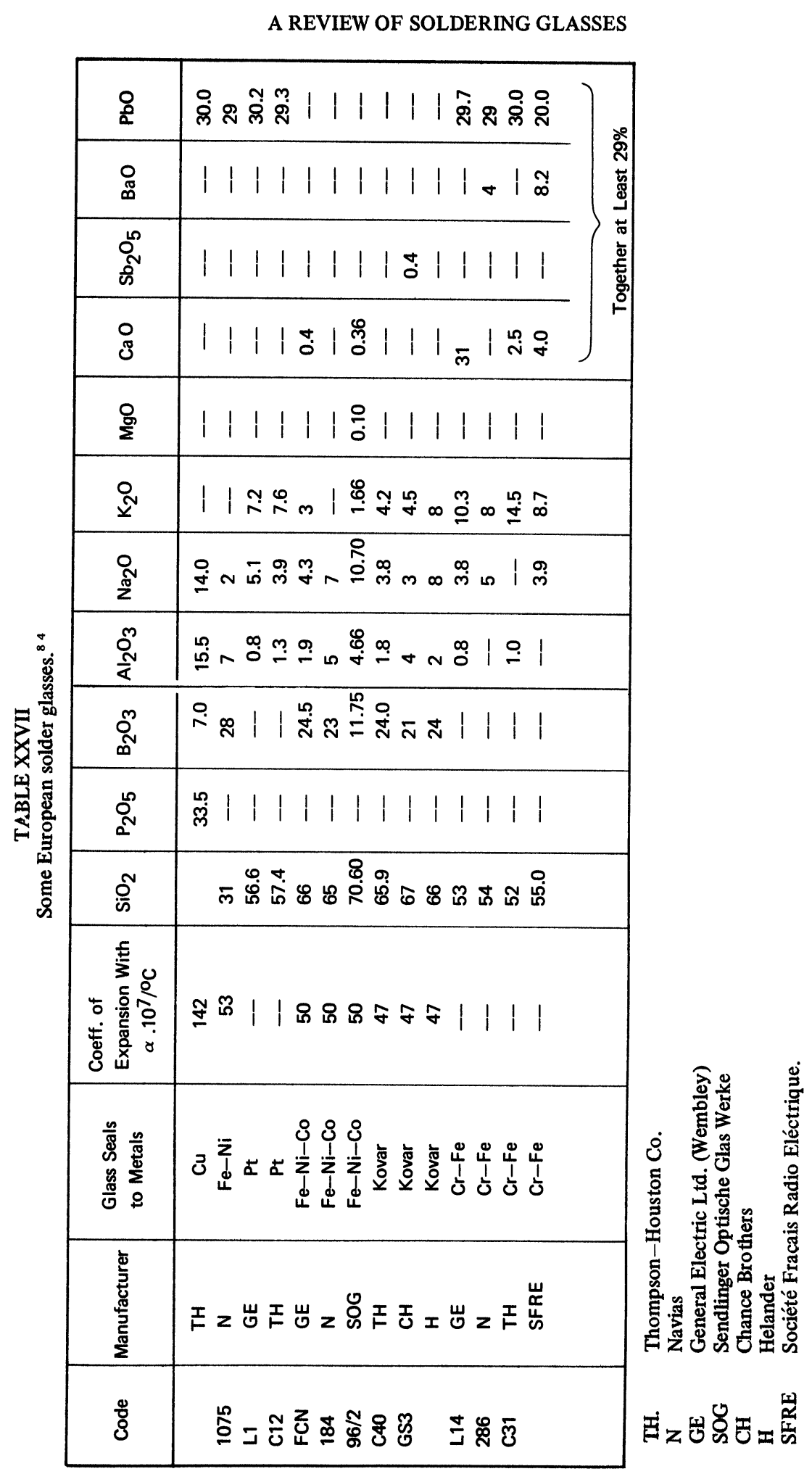




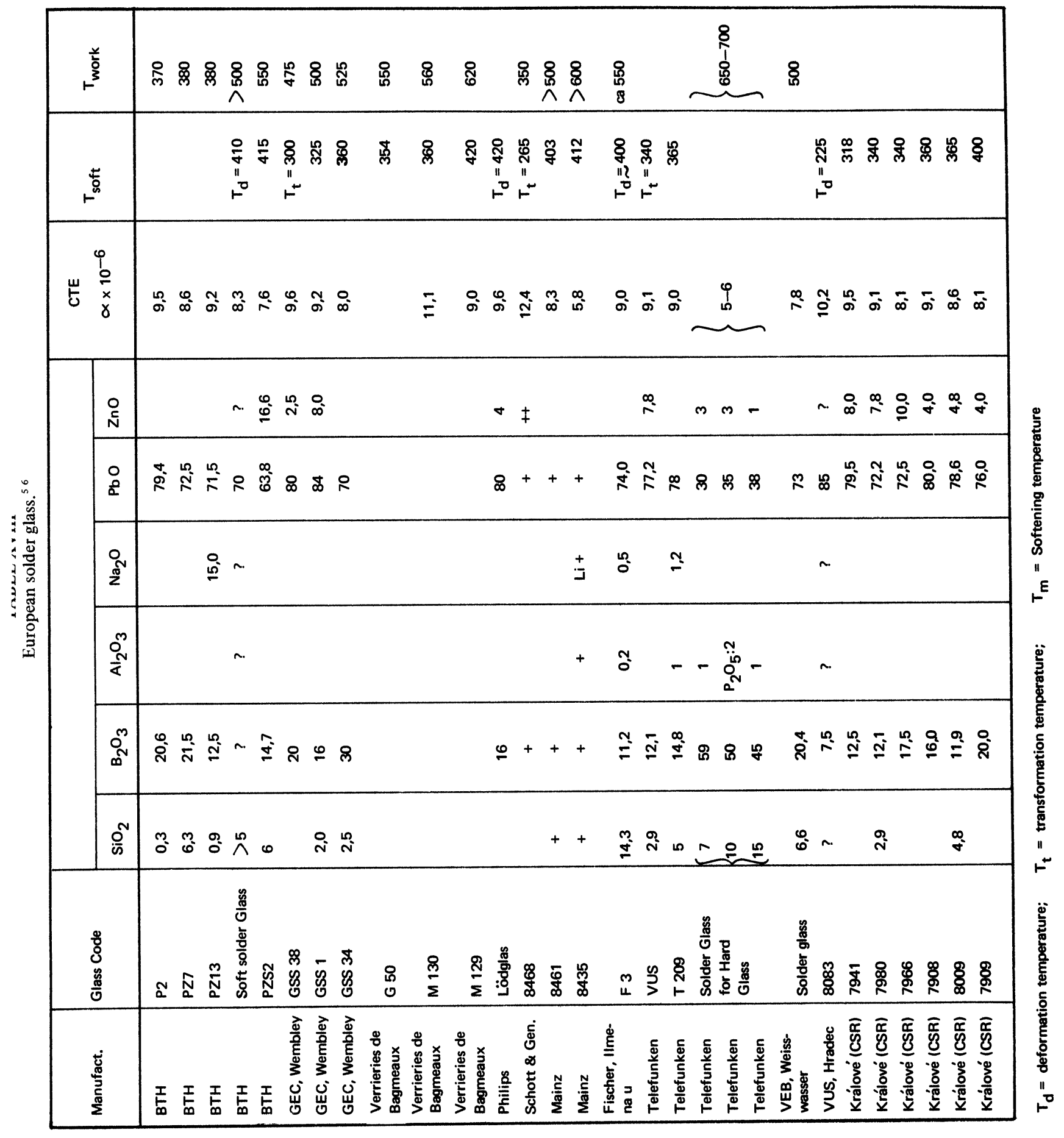




\section{SURVEY OF THE PATENT LITERATURE ON SOLDER GLASSES}

This is essentially a bibliography of foreign and domestic patents.

The patents are organized according to coefficient of expansions. The main constituents and other properties as far as possible are listed briefly. It should be pointed out that the physical properties as listed in the patents are far from complete. Only those properties which are relevant to the invention are listed. Special sealing glasses as well as patents pertaining to glass sealing processes are each listed separately with appropriate comments. Number, country of origin, year of release, inventor and assignors are listed, the latter if available.

$C T E<40 \times 10^{-7} /{ }^{\circ} \mathrm{C}$

U.S 3404015 (1968) Dumbugh, W. H. (C) 3459569 (1969) Ellis, J. L. $\quad$ (O-I) 3564587 (1971) Ellis, J. L. $\quad$ (O-I)

German 2112366 (1971) Baak, N. T. (O-I)

French 1524470 (1968) Borgrave

\section{Devitrifying Glasses}

U.S. 2920971 (1960) Stookey, S. D. (C)

This is the well known "Pyroceram."

Major constituents: $\mathrm{SiO}_{2}>40 \%, \mathrm{Al}_{2} \mathrm{O}_{3}>10 \%$

Minor constituents: Alkalies, $\mathrm{ZnO}, \mathrm{Cu}_{2} \mathrm{O}$, $\mathrm{PbO}, \mathrm{ZrO}_{2}, \mathrm{TiO}_{2}$, alkaline earth metals.

CTE 39 to $42 \times 10^{-7} /{ }^{\circ} \mathrm{C}$

Suitable for sealing to tungsten.

U.S. 2695241 (1954) Calis, J. (Comp. Gen. de

Telegraph, sans fil)

2933552 (1960) Schurecht, H. E.

(Champion Spark plug)

3408222 (1968) Navias, L. (GE)

3469729 (1969) Grekila, R. R. (WE)

German 1046204 (1958) Dallenbach, W.

(FKG FRITZ KESSELRING)

2000412 (1970) Wallis, G.

(Mallory)

German 48342 (1966) Hinz, W.

These glasses are essentially a) Aluminum borosilicates: $\mathrm{SiO}_{2} 30-80 \%, \mathrm{~B}_{2} \mathrm{O}_{3} 0-20 \%$, $\mathrm{Al}_{2} \mathrm{O}_{3} \quad 0-60 \%, \mathrm{CaO} 0-55 \%$, plus various modifiers usually $<1 \%$ or b) High Lead Glasses: $\mathrm{PbO} \quad 60-75 \%, \quad \mathrm{Al}_{2} \mathrm{O}_{3} \sim 10 \%$, $\mathrm{B}_{2} \mathrm{O}_{3} \sim 10 \%$. Sealing temperature for most of these glasses is $\sim 700^{\circ} \mathrm{C}$.

CTE 45 to $51 \times 10^{-7} /{ }^{\circ} \mathrm{C}$

Suitable for sealing to molybdenum

U.S. $\quad 3088834$ (1963) Pirooz, P.P. $\quad$ (O-I)

3088835 (1963) Pirooz, P. P. $\quad$ (O-I)

3113878 (1963) Martin, F. W. $\quad$ (C)
3467509 (1969) Foster, L. C. (Zenith) 3503763 (1970) Mills, W. H. (Anchor-Hockin

French 1451857 (1966) Bristow, R. H. (GE) These are mostly lead-zinc borates glasses, $\mathrm{PbO} 0$ to $25 \%, \mathrm{~B}_{2} \mathrm{O}_{3} 4$ to $25 \%, \mathrm{Al}_{2} \mathrm{O}_{3} 0$ to $20 \%, \mathrm{SiO}_{2} 10$ to $50 \%, \mathrm{ZnO} 50$ to $70 \%$ containing devitrification agents $\left(\mathrm{TiO}_{2}\right.$, $\left.\mathrm{ZrO}_{2}\right)$ and modifiers. The softening temperatures of these glasses are reported to be between $\sim 600$ and $700^{\circ} \mathrm{C}$. Devitrification temperatures $>700^{\circ} \mathrm{C}$ where applicable.

CTE 48 to $62 \times 10^{-7} /{ }^{\circ} \mathrm{C}$

Suitable for sealing to Kovar

U.S. 2693423 (1959) Rogers, F. R.

3088833 (1963) Pirooz, P. P.

$(\mathrm{O}-\mathrm{I})$

3303399 (1967) Hoogendoorn, H. M. (IBM)

3331731 (1967) Baar, N. T. $\quad$ (O-I)

3420684 (1969) Hagendorn, E. C. (O-I)

3420685 (1969) Martin, F.

(C)

3493405 (1970) Thomas, G. L.

(GE)

French 1447732 (1966) Smith, T. P. $2018851(1970)$

(C)

(Jena)

German 1012440 (1957) Sack, W. 1078293 (1960) Ruschke, H. (GE, British)

British 723087 (1955) (Thomson-Houston)

$884004(1955)$

(GE, British)

1209869 (1970) Shipton, G. O. (O-I)

These glasses are mostly $\mathrm{Pb}-\mathrm{Zn}, \mathrm{Al}$, borosilicates. $\mathrm{SiO}_{2} 0$ to $70 \%, \mathrm{Al}_{2} \mathrm{O}_{3} 0$ to $20 \%$, $\mathrm{ZnO} 0$ to $60 \%, \mathrm{~B}_{2} \mathrm{O}_{3} 0$ to $50 \%, \mathrm{PbO} 0$ to $42 \%$ with appropriate modifiers up to $15 \%$ per oxide; or zinc vanadate glasses: $\mathrm{V}_{2} \mathrm{O}_{5} 5$ to $30 \%, \mathrm{ZnO} 40$ to $60 \%, \mathrm{~B}_{2} \mathrm{O}_{3} 20$ to $40 \%$, $\mathrm{SiO}_{2} 0$ to $10 \%, \mathrm{Al}_{2} \mathrm{O}_{3} 0$ to $10 \% \mathrm{PbO} 0$ to $5 \%$. The softening temperature ranges from $\sim 450$ to $800^{\circ} \mathrm{C}$.

$C T E \cong 85$ to $105 \times 10^{-7} /{ }^{\circ} \mathrm{C}$

Suitable for sealing to alloys containing $\mathrm{Fe}-\mathrm{Ni}-\mathrm{C} r$

U.S. 2743553 (1956) Armistead, W. H. $\quad$ (C)

2770923 (1956) Dalton, R. H.

2889952 (1959) Claypool, St. A.

3061664 (1962) Kegg, R. R. (Kimberly)

3473999 (1969) Muchow, G. M. (O-I)

3486871 (1969) Martin, F. W. $\quad$ (C)

3534209 (1970) Anderson, R. C. H. (GE)

Netherlands 6513920 (1966)

Japan 6264 (1962) Yokota, R.

U.S.S.R. 313789 (1969) Yalanskaya, V. A.

These glasses are either high $\mathrm{SiO}_{2}>40 \%$ and low $\mathrm{PbO} \sim 20 \%$ or 
low $\mathrm{SiO}_{2}<5 \%$ and high $\mathrm{PbO}>60 \%$ containing $\mathrm{Al}_{2} \mathrm{O}_{3} 0$ to $10 \%$ and $\mathrm{B}_{2} \mathrm{O}_{3} 0$ to $22 \%$ with alkalis from 0 to $10 \%$ with other modifiers up to $10 \%$. One of the glasses in this group is zinc-vanadates. Softening points range from 400 to $700^{\circ} \mathrm{C}$. Most of these glasses readily devitrify at temperatures $<700^{\circ} \mathrm{C}$.

$C T E \cong 91$ to $100 \times 10^{-7} /{ }^{\circ} \mathrm{C}$

Suitable for sealing to copper and platinum

U.S. 2899575 (1959) Vincent, H. B. (O-I)

2931142 (1960) Veres, F. (O-I)

3075860 (1963) Veres, F. $\quad$ (O-I)

3127278 (1964) Francl, J. (O-I)

3312556 (1967) Oikawa, M. (Hitachi)

3414465 (1968) Baak, N. T. $\quad$ (O-I)

3454408 (1969) Busdiecker, R. A. (O-I)

French 1498179 (1967) Pither, L. F. $\quad$ (O-I)

Glasses in this group are either:

a) High $\mathrm{PbO}>70 \%$ with additions of $\mathrm{Al}_{2} \mathrm{O}_{3}, \mathrm{~B}_{2} \mathrm{O}_{3}$ and $\mathrm{ZnO}$ plus small amounts of modifiers or

b) Low $\mathrm{PbO} 0$ to $50 \%$ with $\mathrm{SiO}_{2}$ 0-90\% plus additions of $\mathrm{V}_{2} \mathrm{O}_{5}, \mathrm{P}_{2} \mathrm{O}_{5}$ and minor amounts of alkali and alkaline earth as well as transition and refractory metal oxides. The softening temperatures range from 300 to $800^{\circ} \mathrm{C}$. The lead vanadates and zinc-lead borates devitrify readily.

$C T E \cong 110$ to $130 \times 10^{-7} /{ }^{\circ} \mathrm{C}$

Suitable for sealing to iron

U.S. 2949376 (1960) Comer, R. L. $\quad$ (GMC)

3240661 (1966) Babcock, C. L. (O-I)

3407091 (1968) Busdiecker, R. A. (O-I)

3408212 (1969) Dumesnil, M. E. (Fairch.)

3480566 (1969)Hoffman, L. C. (DuPont)

3485648 (1969) Bishop, F. L. $\quad$ (O-I)

French 1449425 (1966) (Japan Electric Co.)

These glasses fall into many compositional categories such as aluminoborosilicates, vanadates, plumbates and aluminophosphates, with a large variety of modifiers. Their softening temperature is below $400^{\circ} \mathrm{C}$, usually between 200 to $300^{\circ} \mathrm{C}$. One glass devitrified at $350^{\circ} \mathrm{C}$.

CTE $>130 \times 10^{-7} /{ }^{\circ} \mathrm{C}$

Suitable for sealing to iron

U.S. 2929727 (1960) Oldenfield, L. F.

(GE, British)
2937100 (1960) Oldenfield, L. F.

2948992 (1960) Oldenfield, L. F.

(GE, British)

(GE British)

3203715 (1965) Benbenek, J. E. (RCA)

3449203 (1969) Fisher, H. G. $\quad$ (O-I)

These glasses are aluminosilicates or aluminium borosilicates containing conventional modifier alkalies $0-30 \%$, alkaline earth oxides $0-10 \%$ and devitrifiers $0-30 \%$. The softening temperatures in the range of $500-600^{\circ} \mathrm{C}$.

\section{Special Solder Glasses}

Non-oxide glasses These glasses melt in the range of 100 to $400^{\circ} \mathrm{C}$ but have CTE's over $200 \times 10^{-7} /{ }^{\circ} \mathrm{C}$. These are non-oxide glasses usually ternaries based on the elements $\mathrm{S}, \mathrm{Se}, \mathrm{As}, \mathrm{T} 1, \mathrm{I}$ and $\mathrm{Pb}$ :

U.S. 3144318 (1964) Bruen, Ch. P.

$$
3413187 \text { (1968) Krause, J. T. (BTL) }
$$

Conducting and magnetic glasses This is a lead borate glass ( $\mathrm{PbO} 60 \%, \mathrm{~B}_{2} \mathrm{O}_{3} 10$ to $20 \%$ ) containing $\mathrm{SiO}_{2}$ and $\mathrm{Al}_{2} \mathrm{O}_{3}$ plus Group II oxides in small amounts. $\mathrm{Ag}$ (or $\mathrm{Cu}$ ) plus $\mathrm{Ag}_{2} \mathrm{O}$ not only assures electrical conductivity but reduces devitrification tendencies. A similar basic glass is used loaded (up to $35 \%$ by wt.) with small particles $(<3 \mu$ diam.) to render it magnetic.
U.S. 3080328 (1963) Billian, C. J. (O-I) 3249466 (1966) Lusher, K. G. (O-I)

Resealable solder glass A glass system was developed for repeatedly separating and resealing the same joint by mixing ( $75 \%$ to $25 \%$ ) a devitrifying and non-devitrifying glass. Both glasses belong to the $\mathrm{PbO}-\mathrm{ZnO}-\mathrm{B}_{2} \mathrm{O}_{3}$ system with small amounts of $\mathrm{SiO}_{2}, \mathrm{BaO}$ and $\mathrm{CuO}$ added. This glass has a work temperature of 440 to $532^{\circ} \mathrm{C}$ but devitrifies above that range.

U.S. 3291586 (1966) Chapman, G. C.

$(\mathrm{O}-\mathrm{I})$

\section{Glass Sealing Processes}

This section lists a number of patents describing various techniques of forming glass-to-metal or glassto-glass seals.

Metal seals Both parts to be joined are coated by evaporation or sputtering with a layer of an appropriate metal. The seal then is formed either by a 
conventional solder technique using metal solders or low melting alloys, or by hot or cold pressing.

$\begin{array}{llr}\text { U.S. } & 2918757 \text { (1959) Frackl, J. } & \text { (O-I) } \\ & 306069 \text { (1961) Rhodas, J. L. } & \text { (RCA) } \\ & 3415556(1968) \text { Reed, L. } & \text { (Varian) } \\ & 3481638(1969) \text { Reed, L. } & \text { (Varian) } \\ & 3546363(1970) \text { Pryors, J. } & \text { (Olin Mat.) } \\ \text { British } & 834972(1960) & \text { (English Ind.) } \\ & 940971(1963) & \text { (Philips, Neth.) }\end{array}$

French 1551426 (1968) Pryor, M. J. (Olin Mat.) German 2018752 (1970) Klomp, J. T.

Metal foil seal A suitable metal foil (i.e., Al) is interposed between the two parts (i.e., Sodalime and sapphire) and the parts are heated and or pressed together.

\section{U.S. $\quad 2876596(1959)$ Kessler, S. W. 3424568 (1969) Martin, F. W.}

Glazing techniques In this category the metal part is oxidized appropriately or one or both parts of the work piece are coated with a suitable film of glass or enamel. The seal then is formed by a variety of techniques such as heating under pressure or in a vacuum.

U.S.

$$
\begin{aligned}
& 2422215 \text { (1942) Amberg, Ch. R. } \\
& 2717475 \text { (1955) McCarthy, H. J. (Bomac) } \\
& 2819561 \text { (1958) Henry, K. M. } \quad \text { (O-I) } \\
& 2919210 \text { (1959) Steierman, B. L. (O-I) } \\
& 3107757 \text { (1963) Breadner, R. L. (GE, British) } \\
& 3171771 \text { (1965) Badger, A. E. (Li-O-Ford) } \\
& 3222152 \text { (1965) Upton, L. O. (Am. Opt.) } \\
& 3571487 \text { (1971) Tietze, A. }
\end{aligned}
$$

In situ thickness measurements To measure the thickness of a glass-to-glass seal (or glass-to-metal seal), coloring agents in the solder glass are employed and optical absorption measurements are made after the seal is formed.

\section{Germany (East) $72876(1970)$ \\ ACKNOWLEDGMENT}

The author acknowledges his indebtedness to the IBM System Products Division, East Fishkill library, especially Mrs. K. A. Murley for her assistance in the search, and to P. R. Langston R. R. Tummala and M. N. Turetzky for advice and many helpful discussions and revisions.

\section{REFERENCES}

1. M. B. Volf, "Sealing glasses," Glass Ind., 36 (8), 422 (1953).
2. M. B. Volf, "Sealing glasses," (esp. Chapter 5), Technical Glasses, Sir Issac Pitman and Sons Ltd., London, England, (1961).

3. W. Hinz, and G. Solow, "Devitrifying solder glasses," Silikat Techn., 13, 272-7 (1962).

4. J. L. Gallup, "Properties of low temperature solder glasses," Am. Ceram. Soc. Bull., 36 (2), 47-51 (1957).

5. J. L. Gallup, "Low temperature solder glasses in the electron tube industry," Proc. 6th Symph. Art of Glassblowing Am. Sci. Glassblowers Soc., 90-95 (1961).

6. J. L. Gallup, A. G. F. Dingwall, "Properties of low temperature solder glasses, "Ceram. Bull., 36 (2), 47-51 (1957).

7. O. Knapp, "Devitrification of silicate glasses," Hung. Akad Sci. Publ. (1965).

8. O. Knapp, "Solder glasses, "Silikat Tech., 9 (4), 153-155 (1958).

9. A. E. Dale, and J. E. Stanworth, "Sealing glasses," J. Soc. Glass Techin. 29, 77-91 (1948).

10. A. E. Dale, and J. E. Stanworth, "Development of some very soft glasses," J. Soc. Glass Techn. 33, 167-75 (1949).

11. W. J. Kreidl, "What's happening in glass," Glass Ind., 51 (4), 176-8 (1970).

12. W. H. Kohl, Handbook of Materials and Techniques for Vacuum Devices, Reinhold Pub. Co., New York, N. Y., (1967).

13. J. H. Partridge, Glass-to-Metal Seals, Soc. Glass Techn. Sheffield, England (1967).

14. W. A. Gleason, Five ways to seal glass to metal, Materials in Design Eng., 51 (4), 120-122 (1960).

15. M. W. Riley, "How to select and specify glasses," Materials and Methods, 44 (5), 139-154 (1956).

16. R. H. Dalton, "Solder glass sealing," J. Am. Ceram. Soc. 39 (3), 109-112 (1956).

17. G. W. Morey, The Properties of Glass, Reinhold Pub. Co., New York, N. Y., (1954).

18. G. Bartenev, The Structure and Mechanical Properties of Inorganic Glasses, Wolters-Noordhoff Pub., Groningen, 1970.

19. R. E. Hogan, "Solder glasses," Chem. Tech., 1, 41-43 (1971).

20. J. Broukal, "Contributions to the study of solder glasses used in the vacuum technology," Silikatchn., 13 (12), 428-432 (1962).

21. P. G. Heslop, "Properties of borosilicate glasses," Lab Pract. 17 (9), 1024-26 (1968).

22. J. B. Patrick, Glass to Metal Seals, Aspects of Adhesion, Proc. of Conf. at City Univ. London, 1966 (CRC Press 1968).

23. R. Kleinteich, "Review of glass-metal sealing," Glass Instr. Tech. 8 (8), 553-4 (1964); 8 (10), 705-10 (1964); 8 (11), 778-9 (1964); 9 (1), 22-3 (1965).

24. W. Meier, "Glass-metal seal," Sprechsaal 98 (9), 230-6 (1965)

25. H. E. Simpson, "Value of lead in solder glasses," Glass Ind. , 45 (12), 675-78 (1964).

26. W. S. Eberly, "Glass-sealing alloys," Glass Ind. 44 (8) 435 (1963).

27. M. D. Karkhanavala, and F. A. Hummel, "Thermal expansion of some simple glasses," J. Am. Ceram. Soc., 35 (9), 215-219 (1952).

28. K. H. Sun, and A. Silverman, "Additive factors for calculating the coefficient of thermal expansion of glass 
from its composition," Glass Ind., 22(3), 114-115, 125 (1941).

29. A. A. Appen, "Calculation of physical properties of silicate glasses from their composition," Doklady Akad. Nauk, USSR, 69, 841-44 (1949).

30. Y. Ikeda, and Y. Sameshuma, "Glass to metal bonding," Proc. Jap. Congr. Testing Mater., 124-7 (1963) (Eng.).

31. Y. Ikeda, "Glass to metal bonding mechanism," Zairyo, 17 (180), 783-92 (1968).

32. Y. Sameshuma, and M. Nishiyama, "Bonding mechanism in glass-to-metal seals," Shin Nippon Denki Kiho, 2 (1), 39-51 (1967).

33. W. Espe, "New glass solders in vacuum technology," Feinwerktech., 55 (12), 303-306 (1951).

34. J. A. Pask, and R. M. Fubrah, "Fundamentals of glassto-metal bonding, VIII nature of wetting and adherence," J. Am. Ceram. Soc., 45 (12), 592-6 (1962).

35. N. Aoka, et al., "Low temperature glass," Osaka Koygo Gijutsu Shikenshokiho, 10 (4), 257-63 (1959).

36. W. Hussmann, "Electronic theory of the wetting process," Sprechsaal, 101 (24), 1120-22 (1960).

37. W. A. Weyl, and E. C. Marboe, "Adhesion," Chapter XXIII, Sect. 8; "The Constitution of Glasses," Vol. II, Part 2, J. Wiley, Pub., (1967).

38. R. G. Frieser, "Characterization of Thermally Grown $\mathrm{SiO}_{2}$ Surfaces by Contact Angle Measurements," $J$. Electrochem. Soc., 121 (5), 669-672 (1974).

39. A. Bondi, "Spreading of liquid metals on solid surfaces," Chem. Rev. 52, 417-457 (1953).

40. F. M. Fowkes, Intermolecular and Interatomic Forces at Interfaces, Chapter 8 "Surfaces and Interfaces I," Syracuse Univ. Press (1967).

41. W. D. Kingery, Introduction to Ceramics, J. Wiley and Sons, Inc. (1967).

42. P. L. Beaudouin, "Measurement of Adhesion of Thin Metal Films to their Substrates," Private Communication.

43. P. Benjamin, and C. Weaver, "Adhesion of Metal Films to Glass," Proc. Royl. Soc. A254, 1177-1183 (1960).

44. J. Oroshnik, and W. K. Croll, "Thin film adhesion testing," Surf. Science Symp. Am. Vac. Soc., Albuquerque, N. M. (1970).

45. D. W. Butler, "The stylus and scratch methods of thin film adhesion," Br. J. Phys. D., 3 (6), 877-84 (1970).

46. J. J. Bikerman, Physical Surfaces, p. 189H, Academic Press, New York, N. Y., (1970).

47. R. G. Frieser, "The chromium-glass interface," $J$. Electrochem. Soc., 119 (3), 360-364 (1972).

48. E. P. Denton, and H. Rawson, "Low expansion solder glasses in the system $\mathrm{ZnO}-\mathrm{B}_{2} \mathrm{O}_{3}-\mathrm{V}_{2} \mathrm{O}_{5}$," J. Soc. Glass Techn., 40 (194), 252-259 T (1965).

49. Y. Shirouchi, "Devitrifying solder glasses," Fujitsu Sci. Tech. J., 5 (3), 123-65 (1969) (Engl.).

50. A. Abou-El-Azm, and H. A. El-Batal, "Studies of the softening point of some borate and cabal glasses, and glasses containing high proportion of lead oxide in relation to their structure," Phys. Chem. Glasses 10 (4), 159-163 (1959).

51. H. Schroeder, "Physical-chemical properties of glass surfaces," Glas-Email-Keramic Tech., 14 (5), 161-168 (1963).

52. W. Sack, et. al, "Crystallization of solder glasses," Glas Techn. Ber., 41 (4), 138-145 (1968).

53. G. H. Beall, Refractory Glass-Ceramics, Chapter 2; "High temperature oxides," Vol. 5 Part IV, Academic Press (1971).

54. W. Vogel, "Structure and crystallization behavior of glasses," Angew. Chem Inst. Ed., 4 (2), 112-121 (1965).

55. S. D. Stookey, "Controlled nucleation and crystallization lead to versatile new glass ceramics," C and E News, 39 (25), 116-25 (1961).

56. F. W. Martin, and T. Zimar, Properties and Applications of Devitrifying Solder Glasses, 6th Symp. of American Scientific Glassblowers Soc., 32-41 (1961).

57. D. W. A. Forbes, "Solder glass seals in semiconductor packaging," Glass Techn., 8 (2), 32-42 (1967).

58. E. Umblia, "Low melting glasses," Glastek.Tidskr, 18 (5), 122-129 (1963).

59. F. Bischoff, "Production and examination of some low melting glasses with high dielectric constants," Glastech. Ber., 28 (3), 98-100 (1955).

60. A. Winter, "Glass formation," J. Am. Ceram. Soc., 40 (2), 54-58 (1957).

61. W. A. Weyl, "Nucleation crystallization and glass formation," Sprechsaal, 6, 128-136 (1960).

62. S. Kruszewski, "Gases in glass," J. Soc. Glass Techn., 43 (214), 359-403T (1959).

63. I. N. Semenov, and M. A. Matveev, "Glasses with high elastic properties for connecting joints," Steklo $i$ Keramika, 15 (9), 471-2, (1958) (Engl).

64. J. F. Benzel, "Ceramic-metal adhesive combination," $J$. Am. Ceram. Soc. Bull., 42 (12), 748-51 (1963).

65. E.P. Denton, and H. Rawson, and J.E. Stanworth, "Vanadate glasses," Nature, 173 (4413) 1030-1032 (1954).

66. W. Charles, Cooper, Tellurium Glasses, Chapter 11 "Tellurium" V, Nostrand-Reinhold Co., New York, N.Y., (1971).

67. M. J. Redman, and J. H. Chen, "Zinc tellurite glasses," Am. Ceram. Soc., 50 (10), 523-5 (1967).

68. S. S. Flaschen, et. al, "Formation and properties of low melting glasses in the ternary system As-TI-S, AsTI-Se and As-Se-S," J. Am. Ceram. Soc., 43, 274 (1960).

69. A. D. Pearson, et. al., Advances in Glass Technology Plenum Press, New York, N.Y. (1962).

70. F. C. Lin, and S. M. Ho, "Chemical durability of As-S-I glass," J. Am. Ceram. Soc., 46, 24 (1963).

71. A. K. Yakhkind, "Tellurite glasses," J. Am. Ceram. Soc., 49 (12), 670-75 (1966).

72. A. E. R. Westman, "Constitution of phosphate glasses," Glas Tech. Ber., 36 (12), 500-5 (1962).

73. M. K. Murthy, "Thermal expansion of some alkali phospate glasses," Phys. Chem. Glasses, 7 (2), 69-70 (1966).

74. F. Drexler, and W. Schutz, "Aluminum orthophosphate glasses," Glas. Tech. Ber., 24 (7), 172-176 (1951).

75. D. G. Grossman, and C. J. Phillips, "Zinc borophosphate glasses," J. Am. Ceram. Soc., 47 (9), 471 (1964).

76. H. Hoogendorn, and B. Sunners, "IR absorbing sealing glasses," Am. Ceram. Soc. Bull., 48 (12), 1125-27 (1969)

77. D. W. Roe, "New glass compositions possessing electronic conductance," J. Electrochem. Soc., 112 (10), 1005-9 (1965).

78. M. Bartuska, "Sealing glasses with high electric conductivity," Sklar Keram., 14, 282-5 (1964).

79. S. Pizzini, and A. Bonomi, and P. Colombo, "A simple 
technique for sealing metals to stabilized zirconia by means of glass seals," J.Phys. E. Scien. Inst., 3 (10), 832 (1970).

80. S. Escaich, "Sealing material for glazing purposes," Verre Refract 23 (4), 471-486 (1969).

81. M. J. Lees, "Hafnium-glass seals for low temperatures," Cryogenics, 10 (6), 511-13 (1970).
82. A. Danzin, "Solder glasses of low expansion," Silicates Ind., 8, 312-324 (1953).

83. W. Espe, and J. Slosial, "Vacuum-tight solder glasses," Part I and II Vakuum-Technik, 8 (8), 209-14 (1959), ibid, 9 (1), 7-13 (1960).

84. H. Kalsing, "Solder glasses," Sprechsaal, 86 (15), 363-5 (1953). 

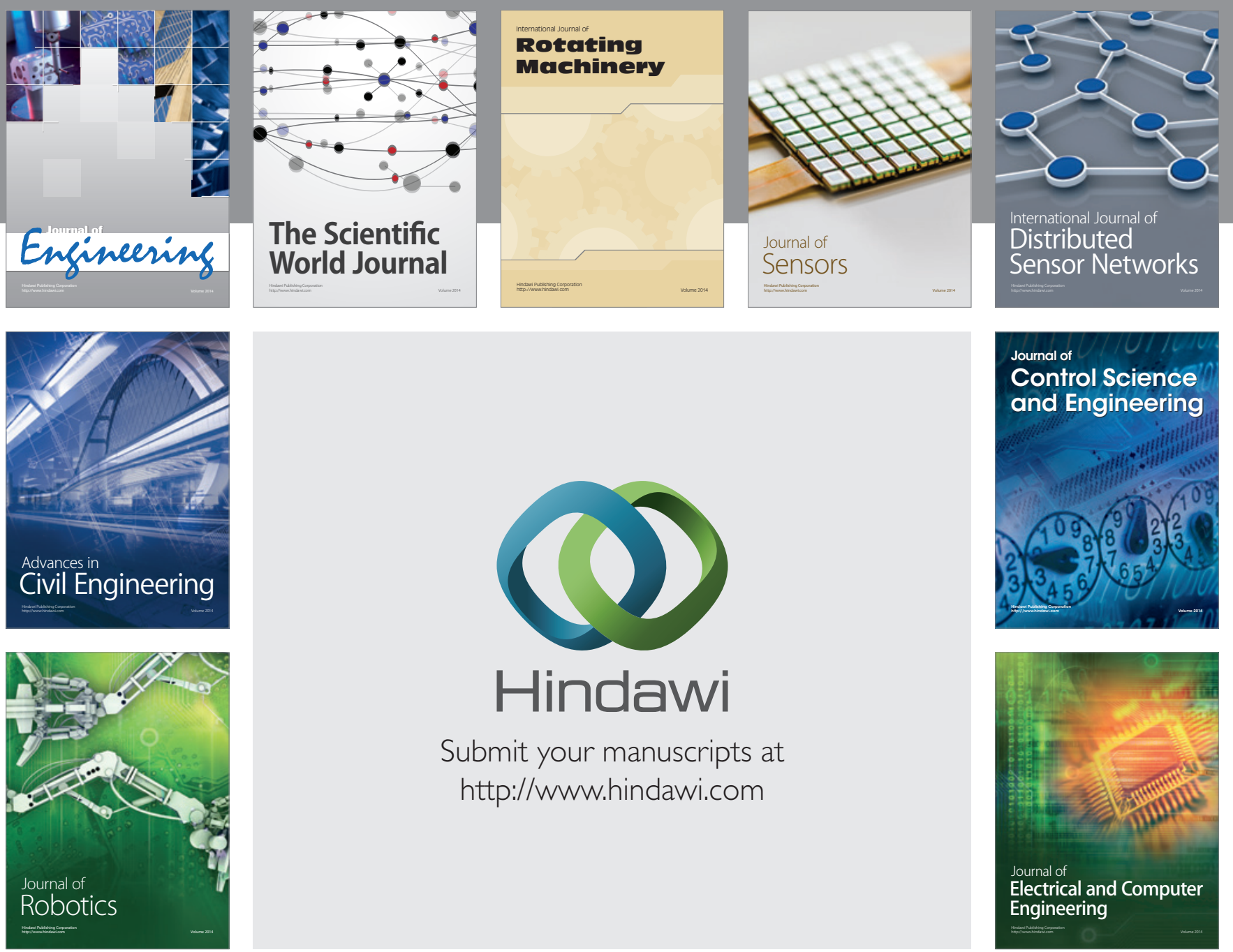

Submit your manuscripts at

http://www.hindawi.com
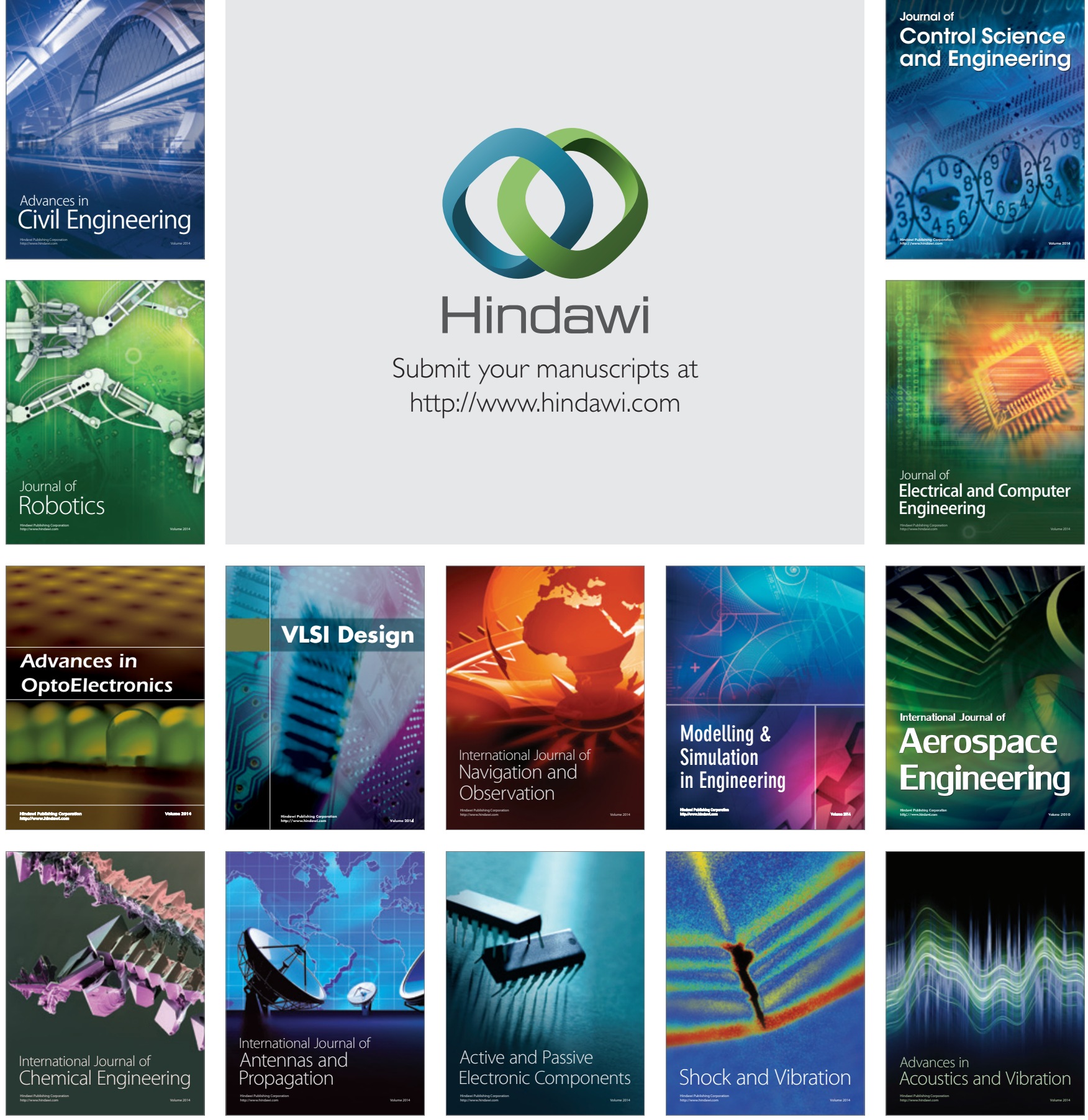